WISSENSCHAFTSZENTRUM BERLIN FÜR SOZIALFORSCHUNG

SOCIAL SCIENCE RESEARCH CENTER BERLIN

Pablo Beramendi

Political Institutions and Income Inequality:

The Case of Decentralization

SP II $2003-09$

September 2003

ISSN Nr. $0722-6748$

Research Area

Markets and Political Economy

Working Group

Institutions, States, Markets
Forschungsschwerpunkt

Markt und politische Ökonomie

Arbeitsgruppe

Institutionen, Staaten, Märkte 
Zitierweise/Citation:

Pablo Beramendi, Political Institutions and Income Inequality: The case of Decentralization, Discussion Paper SP II 2003 - 09, Wissenschaftszentrum Berlin, 2003.

Wissenschaftszentrum Berlin für Sozialforschung gGmbH, Reichpietschufer 50, 10785 Berlin, Germany, Tel. (030) 25491 - 0 Internet: www.wz-berlin.de 


\title{
Political Institutions and Income Inequality: The case of Decentralization
}

\author{
by Pablo Beramendi ${ }^{1}$
}

Political power is being reallocated across territorial boundaries. Traditionally centralized polities are either decentralized or on their way to decentralization. In addition, European nations are engaged in the process of building a common set of rules both respectful to and compatible with their own peculiarities. As a result, the number of political entities in which several levels of government share a common economic space has increased. This paper analyzes how decentralization interacts with the politics of redistribution and inequality. The argument can be outlined as follows. Contrary to what is conventionally argued, decentralization per se does not necessarily lead towards higher (or lower) levels of income inequality. Whatever the impact of decentralization on the distribution of income may be, it is to a large extent a function of the internal structures of inequality within regions and their combination. Secondly, if decentralization indeed leads to different distributive outcomes, there are reasons to believe that, in the context of multilevel governance, contentions about the institutional design of redistribution are themselves contentions about who gets what. Such contentions make decentralization endogenous to the territorial structure of inequality by virtue of a political process linking the latter to the preferences about the institutional design of redistribution. The first part of the paper formalizes this argument. The second one tests its main implications against a data set of 15 OECD countries over the period 19801997.

Keywords: Income Inequality; Decentralization; Redistribution Policy

JEL Classification: $\mathrm{H2}, \mathrm{H3}, \mathrm{D} 6$

I appreciate comments and/or information from Tony Atkinson, Thomas R. Cusack, Gösta Esping-Andersen, Kai Konrad, Jonas Pontusson, Pieter Van Houten, Sig Vitols, Michael Wallerstein, Bruce Western and Chris Wlezien. The usual disclaimer applies. 


\section{Die Auswirkungen von Dezentralisierung auf Einkommensungleichheit}

Politische Macht wird über territoriale Grenzen hinaus neu verteilt. Traditionell zentralisierte Länder haben sich bereits dezentralisiert oder sind auf dem Wege der Dezentralisierung. Zusätzlich befinden sich die europäischen Nationen in einem Prozess des Aufbaus eines gemeinsamen Regelwerkes, das einerseits ihre eigenen Besonderheiten respektieren soll und andererseits mit diesen Besonderheiten vereinbar zu sein hat. Das Ergebnis ist eine Zunahme von politischen Gebilden, in denen sich mehrere Regierungsebenen einen gemeinsamen Wirtschaftsraum teilen. Dieser Artikel analysiert die Interaktion dieses Prozesses mit Verteilungspolitik sowie Ungleichheit und argumentiert dabei wie folgt: Im Gegensatz zur üblichen Sichtweise führt Dezentralisierung nicht notwendigerweise zu höheren (oder niedrigeren) Einkommensungleichheiten. Was immer die Auswirkung von Dezentralisierung auf Einkommensverteilung auch sein mag, so ist letztere zu einem großen Teil das Ergebnis der internen Ungleichheitsstrukturen von Regionen und deren verschiedenen Kombinationen. Und zweitens, wenn Dezentralisierung zu verschiedenen Verteilungsergebnissen führt, dann wäre zu vermuten, dass Konflikte über die institutionelle Ausgestaltung von Verteilungspolitik innerhalb eines Mehrebenensystems eigentlich Meinungsverschiedenheiten über die Frage des „Wer-bekommt-was“ sind. Auf Grund eines politischen Prozesses, der die territoriale Ungleichheit mit den Präferenzen bezüglich der institutionellen Ausgestaltung der Umverteilung zusammenschaltet, werden derartige Konflikte über die Dezentralisierung zu einem endogenen Problem der territorialen Struktur von Ungleichheit. Der erste Teil des Artikels befasst sich mit den eben genannten Argumenten. Der zweite Teil testet deren wesentlichen Implikationen anhand eines Datensatzes von 15 OECD-Ländern über den Zeitraum 1980 - 1997. 


\section{Introduction}

Political power is being reallocated across territorial boundaries. Traditionally centralized polities are either decentralized (Spain) or on their way to decentralization (UK), whilst formerly stable institutional agreements are being revisited in almost every federal country. Last but not least, European nations are engaged in the process of building a common set of rules both respectful to and compatible with their own peculiarities ${ }^{2}$. The arena for contentions about who gets what is being reshaped across advanced industrial societies. As a result, the number of political entities in which several levels of government share a common economic space has increased. This paper analyzes how decentralization interacts with the politics of redistribution and inequality.

The argument can be outlined as follows. If decentralization matters for the distribution of income, it is primarily because it politicizes territorial differences concerning the structure of inequality and the politics of redistribution. Put very briefly, decentralization, by increasing the number of actors with political capacity, alters the nature of the conflicts about who gets what. Whatever the impact of decentralization on the distribution of income may be, it is to a large extent a function of the internal structures of inequality within regions and their combination. For instance, if there is a "socialist" and a "conservative" region, then decentralization will increase redistribution in the former. All in all, this points to the fact that the effect of an institutional change on the overall levels of redistribution is contingent upon a number of determinants. Contrary to what is conventionally argued, decentralization per se does not necessarily lead towards higher (or lower) levels of income inequality. If alternative institutional designs make so much of a difference there are reasons to believe that, in the context of multilevel governance, contentions about the institutional design of redistribution are themselves contentions about who gets what. Thus, there is a second, hidden dimension to the relation between decentralization and inequality in so far as such contentions make decentralization endogenous to the territorial structure of inequality.

\footnotetext{
${ }^{2}$ For a review of these processes see Elazar (1994), OECD (1997), Wright and Hesse (1996) and Amoretti and Bermeo (eds.) (2003).
} 
The remainder of the paper develops this argument in detail and provides empirical evidence to support it. The first section presents a succinct analysis of the distributive consequences of decentralization. On the basis of the implications of such analysis, section 2 develops a model in which the link between the territorial structure of inequality and the preferences about the territorial design of redistribution is identified. Thereafter, a number of hypotheses derived from this model are tested in section 3, exploiting a time-series cross sectional data set for 15 OECD countries during the period 1980-1997. Finally, section 4 concludes.

\section{1.- Decentralization and the Distribution of Income}

Consider the simplest model of redistribution, as developed by Meltzer and Richard (1981: 914-927) on the basis of the previous work by Roberts (1977: 329340) and Romer (1975: 163-185). In this context, a unique redistributive tool is considered, namely a linear income tax with an intercept. This implies that redistribution is simplified to a single dimension, which in turn allows for singlepeaked preferences and the application of the median voter theorem. For the purposes of this section, let me recall the major implication of this model: the amount of redistribution is a function of the relative position of the median voter on the income scale: the larger the distance between the income of the median voter and the average (mean) income in the society, the larger the preferred amount of redistribution ${ }^{3}$. In what follows, I apply this logic to a situation in which there exist several layers of power. By decentralization I refer to a system in which sub-national political entities (regions, states, provinces or, if preferred, nations) are allowed to make their own choices concerning redistribution. Alternatively, under centralization the citizens of all regions are pooled into a common decision making process.

This basic tool allows one to define three basic scenarios that help to explore the link between decentralization and income inequality. Let $Y_{c}, Y_{g}, Y_{n}$ be the

\footnotetext{
${ }^{3}$ Admittedly, this is an oversimplification of the actual politics of redistribution taking place in each of these regions or the nation as a whole. The number of actual determinants of redistribution is much larger, even if considerations about the insurance role of welfare state policies are left aside (Huber et al. 2001; Pierson (ed.) 2001; Iversen and Soskice 2001). However, such oversimplification is, at this point, necessary in order to identify the dimension of interest in this section.
} 
average pre-tax income in areas c, $g$ and $\mathrm{n}$, where subscript $\mathrm{n}$ represents the national level and subscripts $\mathrm{c}$ and $\mathrm{g}$ are regions. Let $\mathrm{Y}_{\mathrm{mc}}, \mathrm{Y}_{\mathrm{mg}}$ and $\mathrm{Y}_{\mathrm{mn}}$ be the median voter's pre-tax income in regions $c, g$ and at the national level, $n$. Finally let $t_{c}, t_{g}, t_{n}$ be the level of redistribution adopted in regions $\mathrm{c}, \mathrm{g}$ and at the national level, $\mathrm{n}$.

Scenario A: $\left(\mathrm{Y}_{\mathrm{mc}} / \mathrm{Y}_{\mathrm{c}}\right)=\left(\mathrm{Y}_{\mathrm{mg}} / \mathrm{Y}_{\mathrm{g}}\right)$; and $\left(\mathrm{Y}_{\mathrm{mc}} / \mathrm{Y}_{\mathrm{c}}\right)=\left(\mathrm{Y}_{\mathrm{mg}} / \mathrm{Y}_{\mathrm{g}}\right)=\left(\mathrm{Y}_{\mathrm{mn}} / \mathrm{Y}_{\mathrm{n}}\right)$ provided that $\mathrm{Y}_{\mathrm{c}}=\mathrm{Y}_{\mathrm{g}}=\mathrm{Y}_{\mathrm{n}}, \mathrm{Y}_{\mathrm{mc}}=\mathrm{Y}_{\mathrm{mg}}=\mathrm{Y}_{\mathrm{mn}}$, but $\mathrm{Y}_{\mathrm{n}} \neq \mathrm{Y}_{\mathrm{mn}}^{4}$.

Scenario B: $\quad\left(\mathrm{Y}_{\mathrm{mc}} / \mathrm{Y}_{\mathrm{c}}\right)=\left(\mathrm{Y}_{\mathrm{mg}} / \mathrm{Y}_{\mathrm{g}}\right) ; \quad$ but $\quad\left(\mathrm{Y}_{\mathrm{md}} / \mathrm{Y}_{\mathrm{c}}\right)=\left(\mathrm{Y}_{\mathrm{mg}} / \mathrm{Y}_{\mathrm{g}}\right) \neq\left(\mathrm{Y}_{\mathrm{mn}} / \mathrm{Y}_{\mathrm{n}}\right)$, because $\mathrm{Y}_{\mathrm{c}} \neq \mathrm{Y}_{\mathrm{g}} \neq \mathrm{Y}_{\mathrm{n}}$.

Scenario C: $\left(\mathrm{Y}_{\mathrm{mc}} / \mathrm{Y}_{\mathrm{c}}\right) \neq\left(\mathrm{Y}_{\mathrm{mg}} / \mathrm{Y}_{\mathrm{g}}\right)$, which implies $\left(\mathrm{Y}_{\mathrm{md}} / \mathrm{Y}_{\mathrm{c}}\right) \neq\left(\mathrm{Y}_{\mathrm{mg}} / \mathrm{Y}_{\mathrm{g}}\right) \neq\left(\mathrm{Y}_{\mathrm{mn}} / \mathrm{Y}_{\mathrm{n}}\right)$.

The first scenario (A) defines the characteristics of a nation where the structure of inequality, i.e., the distance between the income of the median voter and the mean income in each demos, is identical for the two regions and the national level. Thus the preferred level of redistribution in regions $\mathrm{c}$ and $\mathrm{g}$ and at the national level (n) is the same. Under these circumstances the level of decentralization bears no salience for redistribution and inequality. All regions have similar patterns of wealth and income distributions and, subsequently, the integration of all regions results in a nation that resembles each of its parts. Thus it does not matter at which level of government the power to redistribute is allocated to. The distribution of income remains unaltered. This does not necessarily imply that decentralization has no consequences in other realms. These may be related to issues of efficiency gains in relation to the provision of other types of public goods or issues of (dis)economies of scale. Albeit highly unrealistic, this benchmark case illustrates that decentralization has implications for the distribution of income if and only if it is introduced in places in which there is some pattern of regional inequality. This brings us to scenarios $\mathrm{B}$ and $\mathrm{C}$.

In the case of scenario B, the structure of inequality is similar across regions, but, since $\mathrm{Y}_{\mathrm{c}} \neq \mathrm{Y}_{\mathrm{g}} \neq \mathrm{Y}_{\mathrm{n}}$, it is no longer the case that the distance between the mean and the median voter's income is the same at the national level as at the regional level. 
The point to note here is that, even in the rather unlikely case that the structure of inequality is similar across different regions, a change from decentralization to centralization (and vice versa) would imply a change in the preferred level of redistribution. Let me illustrate the point with a numerical example. Assume a union of two regions. Each of the regions has three households. In the first region household incomes are given by 1, 3 and 6 . In turn, in the second region household incomes are given by 4, 12 and 24. Both regions have the same median to mean ratio, i.e., 9/10. However, the ratio at the union level, i.e. considering the six households together, is a different one, namely less than 18/25. In these circumstances, an institutional change from centralization to decentralization would alter the preferred level of redistribution without introducing inter-regional differences. This effect is called hereafter the "between levels" effect of decentralization on the distribution of income. The "between levels" effect points to the fact that an institutional change affects the income distribution because the change in the scale of the political process as such shifts the income of the median voter. Given the conditions specified in B, a shift from decentralization towards centralization would imply no equalization in the levels of redistribution ( $\mathrm{t}$ ) across regions.

Finally, in the far more realistic scenario (C), regions differ not only in their average income levels, but also in their internal distribution of income and, as a result, have different preferences for redistribution. In contrast to $B$, these preferences diverge not only between a hypothetical central government and all the regions, but also among regions themselves. Thus, a shift towards decentralization would impose a change in the scale of redistribution that would be specific to every single region. Conversely, a switch towards centralization would imply not only a change in the scale but also in the homogenization of $\mathrm{t}$ across regions. Scenario $\mathrm{C}$ conveys the "homogenization/diversification" effect of decentralization on the distribution of income. Again, a numerical example is illustrative. Consider two regions with three households each. The income of these households is distributed as follows: 1, 3, 6 is the income of the households in the first region, while 4, 6 and 30 represents the income of the households in the second. Note that the ratio at the

\footnotetext{
${ }^{4}$ If the median and the mean happened to be the same in any given territorial level, in the context of the median voter framework, there would be no need for redistribution.

${ }^{5}$ Levels refer here to central and regional as distinct realms of political authority.
} 
union level is similar to the one in Scenario B, namely less than $18 / 25$. In this case a change from centralization towards decentralization would lead the first region to opt for a level of redistribution given by $9 / 10$. In turn, in the second region, the median to mean ratio is $9 / 20$. The degree of redistribution increases in the second region in relation to both the first region and the union.

A priori, the overall impact of these two effects on the distribution of income is far from obvious. It is certain that decentralization has an effect, but this effect need not work always in the same direction. Therefore, the distributive consequences of decentralization cannot be established a priori. In addition, preferences are defined as a function of the internal structure of inequality in a specific territorial unit and not as a direct reflection of its level of income/wealth. Thus, it is not necessarily the case that poor regions always prefer centralization to decentralization while rich regions always opt for decentralizing (Persson and Tabellini 1994: 765-773). A case in point would be the one of a poor region whose citizens rather keep a decentralized system in order to implement more generous redistributive policies. Furthermore, in the presence of unequal regions the institutional design modifies the preferences for redistribution: citizens that support a particular redistributive policy at the regional level need not automatically support the same one at the national level, and viceversa. Suppose $Y_{c}>Y_{g}$ and $\left(Y_{m c} / Y_{c}\right)>\left(Y_{m g} / Y_{g}\right)$. Under these conditions $t_{c}>t_{g}$, i.e., the rich region is more redistributive than the poor one. If redistribution were to be centralized, citizens in c would support a smaller $\mathrm{t}$ since a majority of citizens in $\mathrm{c}$ would become net contributors and a majority of citizens in $\mathrm{g}$ would be net recipients ${ }^{6}$. All in all, this points to the idea that the specific direction of the effects of an institutional change depends upon the status quo in terms of the structure of inequality.

Precisely on these grounds, it is reasonable to assume that political actors, when deciding about the levels of centralization/decentralization of the welfare state, are aware of the structure of inequality within the different territories, from which they derive an expectation about the level of redistribution to be generated by any specific institutional design. In other words, by deciding on the institutional design

\footnotetext{
${ }^{6}$ For a similar argument applied to different policy issues where the logic of the process leading to a change in preferences is formally depicted, see Rose-Ackerman (1981: 152-165).
} 
they are also making a choice about income redistribution. There is a political process according to which the structure of inequality shapes the levels of decentralization, ultimately a political process accounting for the different relationships between institutional designs and levels of inequality. To put it simply, decentralization is endogenous to income inequality. The question at the core of our problem becomes, then, how the structure of inequality determines the incentives of actors to centralize/decentralize different welfare policies, thereby generating the overall level of decentralization of the welfare state. The next section of the paper turns to this question.

\section{2.- The Model: the Structure of Inequality and the Decentralization of Redistribution}

The development of the argument requires building a link between a number of aspects of the regions' distributions of income and their incentives to choose a particular territorial design of redistribution. In order to identify these aspects and their effects, this section presents a very simple model of institutional choice in which the relevant actors face the problem of

$$
\operatorname{Max}\left(\mathrm{U}(\mathrm{c})_{\mathrm{d}}, \mathrm{U}(\mathrm{c})_{\mathrm{c}}\right)
$$

Where $\mathrm{U}(\mathrm{c})_{\mathrm{d}}$ denotes the value of consumption under decentralization and $\mathrm{U}(\mathrm{c})_{\mathrm{c}}$ denotes the value of consumption under a centralized design of redistribution. Intuitively, the basic problem underlying a decision about the scope of (de)centralization of any given welfare policy is similar to the one underlying the decision to integrate or separate, since decentralization implies separation for that particular policy realm and vice-versa. Therefore, the theoretical work developed in this section takes the Bolton and Roland (1997:1057-1090) and the Alesina and Perotti (1998: 989-1008) models to explain the politics of separation and integration as its point of departure. The main contribution of this paper consists in the incorporation to the analysis of the role of individual specific risks derived from the degree of specialization of the working population in each territorial unit. 
The model starts from its more general form by considering three dimensions of the problem, namely the differences between regions in terms of average income, the differences between regions in terms of the incidence of individual specific risks and, thirdly, the role of the exposure to regional specific shocks. In a second step, the problem is simplified by assuming away the impact of external shocks. This facilitates a more precise treatment of the link between the different dimensions of the structure of inequality and the incentives underlying the institutional choice can be developed. Before presenting the argument in full, I turn now to discuss the assumptions on which it is built.

\section{1.- Assumptions}

A.1.- Neither citizens nor endowments are allowed to move between regions in response to the nature of different redistributive policies. This simplifies the analysis by freezing the strategic interactions between regions.

A.2.- The decision about the institutional design of redistribution is to be made before the economic outcome is known, i.e., (1) before the representative individual of the region knows which sector he/she is going to end up in and/or (2) before it is known which region is the lucky one. This rather unrealistic assumption is helpful in that it makes unnecessary to identify specifically in which sector the median voter is.

A.3.- Redistribution is performed via a linear tax with an intercept. This allows to assume that the level of redistribution is determined by a single issue majority vote.

A.4.- A Union with two regions is considered. Regions have very simple economies. Regions are assumed to have three sectors: $\alpha, \beta$ and $\lambda$.

The $\alpha$ sector represents the share of the working population that works in a sector with no individual specific risks, but exposed to regional specific ones. These risks take the form of a shock (S) that, following Alesina and Perotti (1998: 9891008), is assumed to be negatively perfectly correlated between the two regions. In other words, for one lucky $(S=1)$ region in the union there is necessarily an unlucky 
$(S=-1)$ one. Let $(1+S)$ represent the external shock affecting people working in the $\alpha$ sector. $\beta$ represents the sector of the population that derive their income from labor market activities subject to individual specific risks. Hence $\alpha(1-t) \mathrm{w}_{\mathrm{i}}(1+\mathrm{S})$ and $\beta(1-$ t) $\mathrm{w}_{\mathrm{i}}$ denote the after tax income of the people in the two working sectors of the economy. Finally, $\lambda$ represents the non-working population, whose income comes from the share of aggregate output per capita $(y)$ that has been taxed $(y t)$. So let (1-t) $\mathrm{W}_{\mathrm{i}}$ denote the after tax income of the people in the working sector of the population $(\beta)$. Finally, let $\left(t-t^{2} / 2\right) y$ be the income of the people ending up in the $\lambda$ sector, where $\mathrm{t}^{2} / 2$ captures, conventionally, the deadweight losses of redistribution.

A.5.- Risks imply uncertainties about income. In the case of $\alpha$, these uncertainties are a function of the probability of being subject to an external shock. In the case of $\beta$, the uncertainties derive from individual specific risks, associated with the degree of economic specialization. $\sigma_{\mathrm{z}}$ will denote the variance due to the individual specific risks, whereas, in turn, $\sigma_{\mathrm{s}}$ will denote the variance of the regional specific shock. The definition of the expected utility of each of the sectors $(\alpha, \beta)$ affected by income risks is modeled using a quadratic utility function of the following form (Varian 1980:49-67). Let $\mathrm{z}$ represent the income of the sector with individual specific risks. Then,

$$
\begin{aligned}
& \mathrm{E}(\mathrm{u})=\mathrm{E}\left(\mathrm{z}-\mathrm{z}^{2} / 2\right), \text { where } \\
& \mathrm{E}\left(\mathrm{z}^{2}\right)=\mathrm{E}(\mathrm{z})^{2}+\operatorname{var} \mathrm{z} \\
& \text { and } \\
& \text { var } \mathrm{z}=\sigma^{2} \mathrm{w}^{2}(1-\mathrm{t})^{2} .
\end{aligned}
$$

A.6.- Finally, in order to keep the analysis manageable, other aspects of the politics of the institutional design needs to be simplified. In line with previous models (Bolton and Roland 1997: 1057-90), I assume that there is a union, in our case, centralization, only if it is unanimously accepted by the regions. By doing so the institutional specificities of the interactions between regions are frozen and the link between the structure of inequality and the institutional design of redistribution become more isolatable and tractable. Hence the usefulness of this assumption. 


\section{2.- The Structure of Inequality and the Institutional Choice ${ }^{7}$.}

Taken together, these assumptions imply that the utility function of any given territorial level must be defined as a function of two unknown variables and their interaction through the tax rate: (1) whether or not the external shock (S) is positive or negative; (2) the incidence of individual specific risks; and (3) the fact that the tax base and the tax rate affecting all three sectors are also a function of the external shock. More formally:

$$
E U(c)=\alpha \int U(S) d F(S)+\beta \iint U\left(S z_{i}\right) d F(S) d G\left(z_{i}\right)+\lambda \int U(S) d F(S)
$$

where $\mathrm{S}$ captures the unknown external shock and $\mathrm{z}_{\mathrm{i}}$ the incidence of unknown individual specific risks. The evaluation of (1) across two different institutional regimes encompasses two analytically different issues regarding the institutional choice: the impact of the structure of inequality within each region on the institutional choice on the one hand and the impact of external shocks (S) on the other. Of these two issues, this paper is mainly concerned with the first one. Thus, in order to simplify the analysis, I shall introduce one further assumption: regions are not exposed to external shocks while facing the institutional choice. In terms of our model, $\alpha=0$. In this way ${ }^{8}$, the link between the structure of inequality within regions

\footnotetext{
${ }^{7}$ Notation: the absence of a subscript implies reference to the regional level. Subscript $u$ indicates reference to the union level. So for instance $\mathrm{w}_{\mathrm{i}}$ represents the pre-tax income of an individual of the region whereas $\mathrm{w}_{\mathrm{iu}}$ represents the pretax income of an individual of the union. Similarly $\mathrm{w}_{\mathrm{m}}$ represents the pretax income of the median voter of the region whereas $\mathrm{w}_{\mathrm{mu}}$ represents the pretax income of the union's median voter.

${ }^{8}$ Note that this assumption does not imply to consider external shocks irrelevant for the institutional choice. Rather it is meant to be a more straightforward ceteris paribus condition. For a detailed inclusion in the model of the role of regional specific shocks and an empirical test of its implications see Beramendi (2003). According to the more extended version of the model, a shock S may interact with the units in different ways. If it affects all the units in the same way, it encourages centralization by increasing risk sharing. If alternatively, it affects the risks structure of the units $(\lambda, \sigma)$ differently, it reinforces the trade-offs by generating a situation of partial risk pooling. In fact, under specific circumstances the need to overcome the different tradeoffs can be equally shared across regions, generating the rationale for institutional innovation. Historically, for those fields in which this tradeoff is very tight, modern federations have overcome it by making the institutional design of redistribution bi-dimensional (Buchanan 1950: 583-599; Boadway 2001: 103-110; Cremer et al. 1997: 325-335). In a hypothetical situation in which all regions face a unit specific risk (S), albeit at different levels, while all of them are specialized in different sectors of production, the model predicts that decentralization prevails. However, both regions would agree to develop a system of interregional transfers that provides some insurance against S. Indeed Alesina et al. (2001) have identified this combination as the most efficient institutional rule for federations in that it respects local differences at the same time as providing insurance to the regions. Nevertheless in this kind of context
} 
and the institutional choice can be isolated and identified more clearly. The model is now concerned with just two aspects of the problem, namely the differences between regions in terms of average income and the region differential in terms of individual specific risks.

The individual specific risks are assumed to be the result of different degrees of economic specialization. By definition specialization implies that the number of possible alternatives in the event of an adverse shock is smaller. As a result, both employers and employees in that sector/region bear higher income risks. As argued by a recent stream of welfare state research (Mares 2001: 184-213; Estevez, Iversen and Soskice 2001; Iversen and Soskice 2001: 875-895), this fact conditions heavily their preferences about redistribution. The higher the levels of asset specificity (which parallels economic specialization), the higher the support for redistribution and the more likely it is that employers and employees will endorse a common and more generous policy. And this is so because, for higher levels of specialization, the insurance motive is likely to dominate the standard rich versus poor conflict. Employers no longer associate less efficiency with more redistribution. Rather, redistribution becomes a form of insurance that facilitates the working of the economy. From here it follows that in a very specialized sector of the economy, contributors and potential recipients have something to gain from a commonly agreed redistributive policy within any given territory.

This logic is also very relevant for the analysis of preferences regarding different institutional designs, in that specialized regions are likely to show a rather different structure of incentives compared to non specialized ones ${ }^{9}$. The losses

the efficiency gains may be undermined by a potential moral hazard problem pointed out by Persson and Tabellini (1996b: 623-646): localities may undertake redistributive policies that increase the probability of having a unit specific shock.

\footnotetext{
${ }^{9}$ Specialization also matters in that it affects factor mobility. In the presence of specialization, perfect factor mobility is no longer in place. A highly specialized sector of the labor force is less reemployable anywhere else in the country. Hence, those individuals have little incentives to move since there is not much demand for their skills. A prominent example here is provided by the fishermen of Nova Scotia (Canada). A similar logic applies to capital: specialized industries need labor with a particular set of qualifications that is not necessarily available all over the country. Thus they have an incentive to sacrifice some of their returns, in the form of taxes, to employ a better equipped labor force, as opposed to moving automatically to any region offering a capital tax reduction equal to or higher than the sum of the moving and the fixed cost left behind. Specialized capital and labor are, overall, less mobile, which in turn increases even further their exposure to risk (Wildasin 1995: 527546) and binds them to agree on a set of common redistributive policies that suits the working of an
} 
attached to possible adverse circumstances are larger and so is the uncertainty about future income. In this context, it is possible to conceive of a theoretical link between the degree of specialization and the evaluation of the insurance properties of different territorial designs of the welfare state ${ }^{10}$.

In an economy in which $\alpha=0$, the expected utility function of a representative individual at the regional level is defined as follows:

$\mathrm{EU}(\mathrm{c})=\beta \int \mathrm{U}\left(\mathrm{z}_{\mathrm{i}}\right) \mathrm{df}\left(\mathrm{z}_{\mathrm{i}}\right)+\lambda \mathrm{yt}-\lambda \mathrm{yt}^{2} / 2$

Where $z_{i}$ depicts the unknown incidence of individual specific risks. Equivalently,

$\mathrm{EU}(\mathrm{c})=\beta\left[\mathrm{w}_{\mathrm{i}}(1-\mathrm{t})-\mathrm{w}_{\mathrm{i}}^{2}(1-\mathrm{t})^{2}\left(1+\sigma_{\mathrm{z}}^{2}\right)\right]+\lambda \mathrm{yt}-\lambda \mathrm{yt}^{2} / 2$

Any given individual will choose the tax rate that maximizes her after tax income. Hence the relevant partial derivative becomes:

$\partial \mathrm{E} / \partial \mathrm{t}=-\beta \mathrm{w}_{\mathrm{i}}+(1-\mathrm{t}) \lambda \mathrm{y}+(1-\mathrm{t})\left[2 \beta \mathrm{w}_{\mathrm{i}}^{2}\left(1+\sigma_{\mathrm{z}}^{2}\right)\right]$

being the solution to the resulting first order condition as follows:

$\mathrm{t}^{*}=1-\beta \mathrm{w}_{\mathrm{i}} /\left\{\lambda \mathrm{y}+\left[2 \beta_{\mathrm{wi} 2}\left(1+\sigma_{\mathrm{z}}{ }^{2}\right)\right]\right\}$

Similarly, it is possible to define the tax rate that an individual of a union $(\mathrm{u})$ chooses where one sector of the working population is exposed to a certain degree of individual specific risks while the other sector of the population consists of the dependent population. Note that,

$$
\beta_{\mathrm{u}}=\left(\beta_{1}+\beta_{2}\right) /\left(\alpha_{\mathrm{u}}+\beta_{\mathrm{u}}+\lambda_{\mathrm{u}}\right),
$$

which is to say that the relative weight of the economically specialized sector in the union is not necessarily similar to the one in the region. Nor it is, as a result, the

economy. The expected pattern of behavioral responses by market actors to redistribution can then be considered a function of specialization.

${ }^{10}$ On the conception of redistributive taxation as a provider of social insurance see Varian (1980: 4967), Atkinson (1995) and Sinn (1995: 495-526). 
incidence of individual specific risks for workers in $\beta_{\mathrm{u}}$. By analogy, the tax rate chosen by any member of the union will be the one that maximizes the union's members after tax income, i.e.,

$\mathrm{t}_{\mathrm{u}} *=1-\beta_{\mathrm{u}} \mathrm{W}_{\mathrm{iu}} /\left\{\lambda_{\mathrm{u}} \mathrm{y}_{\mathrm{u}}\left[2 \beta_{\mathrm{u}} \mathrm{W}_{\mathrm{iu}}{ }^{2}\left(1+\sigma_{\mathrm{zu}}{ }^{2}\right)\right]\right\}$

From (2) and (3) it is straightforward to see that the larger the dependent population, the larger the preferred tax rate. In addition, consistent with previous insights (Varian 1980: 49-67; Iversen and Soskice 2001: 875-895), expressions (3) and (4) also show that when the risk inherent to the people working in the specific sector increases, the preferred tax rate also increases, paralleling the demand for insurance. And this holds for any given territorial unit under consideration. Other things being equal, an increase in $\sigma$ leads to a reduction in (1-t) and therefore to an increase in $\mathrm{t}$.

At this point, in line with Bolton and Roland (1997:1057-1090) and Alesina and Perotti (1998: 989-1008), assumption A.3 helps simplify the problem very much. Under the conditions outlined in A.3, (1) the equilibrium tax rate is the tax rate chosen by the median voter in both the union and the region and, equally, (2) the decision to centralize/decentralize will be driven by the evaluation of the difference between the expected utility of the median voter under decentralization and the expected utility of the median voter under centralization, i.e., when the tax implemented is the one chosen by the union's median voter.

In order to perform such an exercise, it is necessary to substitute the relevant tax rates of the two institutional regimes into the utility function of the regional median voter. The utility function of the regional median voter can be generally defined as:

$\mathrm{EU}_{\mathrm{m}}(\mathrm{c})=\beta\left[\mathrm{w}_{\mathrm{m}}(1-\mathrm{t})-\mathrm{w}_{\mathrm{m}}{ }^{2}(1-\mathrm{t})^{2}\left(1+\sigma_{\mathrm{z}}{ }^{2}\right)\right]+\lambda \mathrm{yt}-\lambda \mathrm{yt}^{2} / 2$

whereas the relevant tax rates are: 
$\mathrm{t}_{\mathrm{m}}=1-\beta \mathrm{w}_{\mathrm{m}} /\left\{\lambda \mathrm{y}+\left[2 \beta \mathrm{w}_{\mathrm{m}}^{2}\left(1+\sigma_{\mathrm{z}}^{2}\right)\right]\right\}$

and

$\mathrm{t}_{\mathrm{mu}}=1-\beta_{\mathrm{u}} \mathrm{W}_{\mathrm{mu}} /\left\{\lambda_{\mathrm{u}} \mathrm{y}_{\mathrm{u}}\left[2 \beta_{\mathrm{u}} \mathrm{w}_{\mathrm{mu}}{ }^{2}\left(1+\sigma_{\mathrm{zu}}{ }^{2}\right)\right]\right\}$

By substituting (5) and (6) into (4), the utilities of the regional median voter under the two regimes are obtained. Thereafter, we are in a position to evaluate the differences between the two. Once these calculations are made, the following expression is obtained:

$\mathrm{EU}_{\mathrm{m}}(\mathrm{c})_{\mathrm{d}}-\mathrm{EU}_{\mathrm{m}}(\mathrm{c})_{\mathrm{c}}=$

$1 / 2\left(\mathrm{y}-\mathrm{y}_{\mathrm{u}}\right)+$

$\beta w_{m}\left[2 \beta w_{m}-\lambda y-a\right] / 2[\lambda y+a]-\beta w_{m u}\left[2 \beta w_{m}-\lambda y-a\right] / 2\left[\lambda_{u} y_{u}+a_{u}\right]$

where $\mathrm{a}=\left[2 \beta \mathrm{w}_{\mathrm{m}}^{2}\left(1+\sigma_{\mathrm{z}}{ }^{2}\right)\right]$ and $\mathrm{a}_{\mathrm{u}}=\left[2 \beta \mathrm{w}_{\mathrm{mu}}{ }^{2}\left(1+\sigma_{\mathrm{zu}}{ }^{2}\right)\right]$ are, respectively, the terms capturing the individual specific risks at the regional and the union level. Given that (8) is not self-evident, I shall discuss the implications of the model using two numerical examples. Table 1 presents two simulations based on expression (8). In both cases the region is poorer than the union. In the first simulation this is the only feature that distinguishes the region from the union. The second simulation is identical to the first one, except in that it introduces a second dimension of difference between the region and the union; namely, it allows for differences in terms of the incidence of individual specific risks. 
Table 1. - Implications of Model I: Numerical examples.

\begin{tabular}{|c|c|}
\hline \multicolumn{2}{|c|}{ Scenario I: The impact of differences in terms of average income. } \\
\hline Conditions & $E U_{m}(c)_{d}-E U_{m}(c)_{c}$ \\
\hline $\begin{array}{l}\beta \mathrm{w}_{\mathrm{m}}=\beta \mathrm{w}_{\mathrm{mu}}=4 \\
\mathrm{y}=6 ; \mathrm{y}_{\mathrm{u}}=7 \\
\lambda_{\mathrm{u}}=\lambda=0.5 \\
\sigma_{\mathrm{z}}^{2}=\sigma_{\mathrm{zu}}^{2}=1 ; \mathrm{a}_{\mathrm{u}}=\mathrm{a}=64\end{array}$ & -0.6 \\
\hline \multicolumn{2}{|c|}{ Scenario II: Adding differences in terms of incidence of individual specific risks. } \\
\hline Conditions & $E U_{m}(c)_{d}-E U_{m}(c)_{c}$ \\
\hline $\begin{array}{l}\beta \mathrm{w}_{\mathrm{m}}=\beta \mathrm{w}_{\mathrm{mu}}=4 \\
\mathrm{y}=6 ; \mathrm{y}_{\mathrm{u}}=7 \\
\lambda_{\mathrm{u}}=\lambda=0.5 \\
\sigma_{\mathrm{z}}{ }^{2}=2 \mathrm{a}=160 ; \sigma_{\mathrm{zu}}{ }^{2}=1 \quad \mathrm{a}_{\mathrm{u}}=64\end{array}$ & +0.1 \\
\hline
\end{tabular}

Scenario I illustrates very well the importance of the income differences between the regions in the politics of institutional choice. In the absence of any other difference poorer regions have an incentive to opt for centralization since, under such a design, they are able to capture part of the income of their wealthier partners. These, on the other hand, would have no incentive to centralize at all. Similarly expression (8) indicates how differences across regions in terms of their share of the dependent population shape the incentives for decentralization. For those regions where the incidence is low, decentralization is the obvious choice. Yet this is only part of the story.

The comparison between scenarios I and II shows that when other dimensions of inequality are taken into account, poor regions face a trade-off between the interregional income transfers implicit to centralization and their capacity to maintain their preferred policy choice in order to cope with their own specific labor market risks. Scenario II exemplifies how, in the presence of sufficiently large differences in terms of the incidence of individual specific risks, the payoffs of centralization are overcome by the costs of having the union's preferred level of redistribution imposed. A specialized poor region may choose to stay on its own in order to protect its capacity to chose how much redistribution is to be provided. This is exemplified 
by the fact that the differential between utilities goes from - 0.6 (centralization as the preferred outcome) to 0.1 (decentralization the preferred outcome) even in the presence of identical income differences.

An alternative way of thinking about the incidence of individual specific risks is the following. Suppose that $\mathrm{y}_{\mathrm{u}}=\mathrm{y} ; \mathrm{w}_{\mathrm{m}}=\mathrm{w}_{\mathrm{mu}}, \lambda_{\mathrm{u}}=\lambda$ but $\sigma_{\mathrm{z}}{ }^{2} \neq \sigma_{\mathrm{zu}}{ }^{2}$, and recall that expression (6) maximizes (2). Under these conditions designs other than decentralization can at best make the regional median voter indifferent between the two. The implications for the relation between the tax preferred in each of these cases and the utilities expected by the regional median voter are represented in Figure 1.

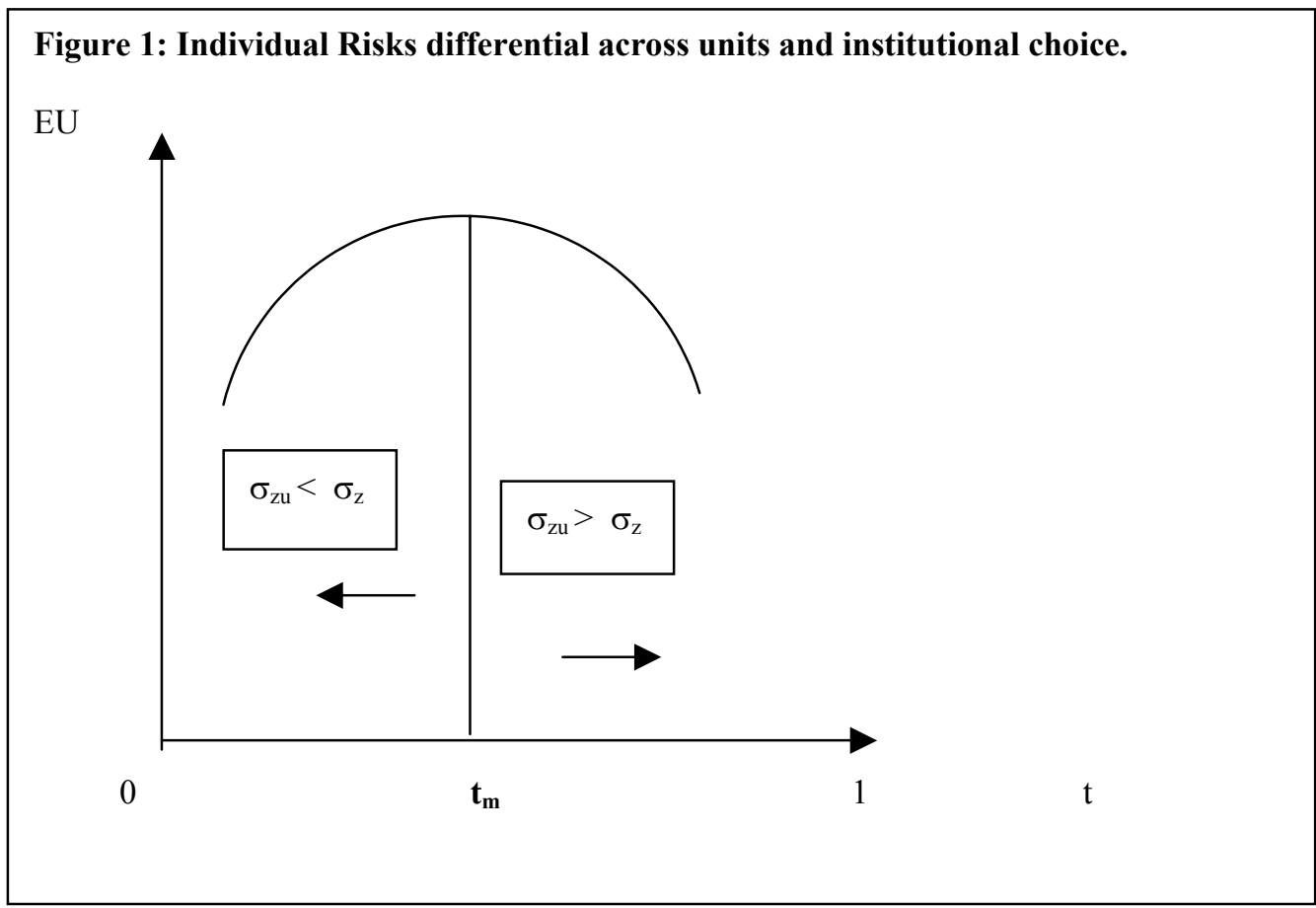

From expressions (6) and (7) it is easy to see that as $\sigma_{\mathrm{z}}{ }^{2}<\sigma_{\mathrm{zu}}{ }^{2}, \mathrm{t}_{\mathrm{m}}>\mathrm{t}_{\mathrm{mu}}$, which, as depicted in Figure 1, implies a decrease in the expected utilities of the regional median voter. Hence, unless $\sigma_{\mathrm{z}}=\sigma_{\mathrm{zu}}$ no alternative institutional design is considered, which is to say that any institutional option that implies a change in any of the parameters defining the current structure of inequality will be rejected by the regional median voter. In relation to the issue of concern in this section, the implications are clear. Differences across regions in the level of economic 
specialization generate incentives for decentralizing because they imply varying degrees of exposure to income risks by individuals in different regions, which in turn, generates differences in the degree of public insurance demanded by citizens across regions. In other words, economic specialization enhances decentralization in that it widens the differences across regions regarding the preferences for redistribution. Indeed, specialization may shape the politics of redistribution across territorial units even up to the point of overcoming the pro-centralization incentives of lower income regions, as illustrated above.

The thrust of the model presented above is that the choice of the level of decentralization of redistribution is endogenous to the structure of inequality because of the income differential on the one hand and the patterns of risk sharing between regions on the other. Consider two regions $\mathrm{A}$ and $\mathrm{B}$ deciding whether or not to centralize a particular redistributive policy. A and B share risks fully if they have a similar degree of exposure to $\mathrm{S}$ (in this case 0 ) and their distributions of income are structured in a similar way. Under these circumstances centralization is the obvious institutional choice. The opposite happens when the degree of exposure to external shocks varies and inequality is structured differently across regions. Decentralization is the obvious outcome since at least one of the regions has no incentive to centralize redistribution ${ }^{11}$.

However, risk sharing is seldom clearly defined, though. A large share of institutional choices demand from regions to balance how much autonomy they are willing to exchange from insurance and vice-versa. Provided that regions differ in income, poor regions must trade-off the cost of having a policy different from the one they would have chosen for the gains from being able to obtain some of the richer regions' wealth. The dilemma of wealthier regions is, in principle, easier since they have no incentive to centralize. Moreover, even in the hypothetical case that

\footnotetext{
${ }^{11}$ The institutional outcome in this context is also affected by the number of regions and their specific characteristics as well as by the procedure to adopt the collective choice (Persson and Tabellini 2000: 159-201). Note also that the idea that decentralization of redistribution is more likely to take place when social risks are not shared between regions is perfectly consistent with more normative considerations concerning the benefits of decentralization as a tool for dealing with informational problems associated with the functioning of the policy (see, among others, Oates 1999: 1120-1149). However, even so, the model shows that the underlying causal logic is a different one. Informational advantages may well help explain why a particular design remains over time, but tracing its origins to its alleged functional advantages subverts the sequence of causation.
} 
regions do not differ largely in income a typical situation may involve differences in terms of individual specific risks $(\sigma)$, but some degree of similarity in terms of the share of the dependent population $(\lambda)$. To conclude, for any given union, the choice of a particular territorial design of redistribution depends upon the internal composition of the union in terms of regional incomes and risk structures. The next section turns to the empirical analysis of the relation between decentralization and income inequality in light of the implications of the model.

\section{3.- Decentralization and Income Inequality: Empirical Analysis}

\section{1.- Derivation of Hypotheses}

At the core of the argument developed in the previous section is the idea that, because actors have an expectation about the effects of any given institutional change, the design and evolution of institutions (in this case, the decentralization of redistribution) is endogenous to the structure of inequality. The causal story would not be, as conventionally assumed in the literature (see below), one about exogenous effects of intrinsically inegalitarian institutions. Rather, it is one in which, given a particular structure of inequality, a political process determines the selection of institutions according to (i) their expected distributive effects and (ii) the dominating preferences among the relevant actors. Hence if decentralization is endogenous to inequality it is precisely because it is expected to interact with those dimensions that make regions diverge in their preferences about redistribution. Such an interaction, in turn, becomes a function of the territorial distribution of specialized economic sectors, the regional shares of dependent population and the extent to which there are region-specific shocks. As it stands, two major implications can be derived from this argument for the empirical analysis of the impact of decentralization on income inequality.

a) The dominant approach in the studies about the impact of decentralization on redistribution and inequality is to consider decentralization as exogenous to the dependent variable ${ }^{12}$. If, according to the argument of this paper, it is thought

\footnotetext{
${ }^{12}$ Previous contributions to the literature, in assuming that causality worked only from decentralization towards redistribution and inequality, have both excluded inequality as a determinant of decentralization (Garrett and Rodden 2003; Panizza 1999: 97-139) and, more importantly, ignored the problem of endogeneity when analyzing the impact of decentralization on redistribution and inequality (Huber et al. 1993: 711-750; Huber and Stephens 2001).
} 
otherwise, it seems reasonable to believe that the effect identified by previous approaches is due, in some proportion, to reverse causality. In fact, if the theory is correct, the magnitude of the upward bias due to reverse causality should be large enough to alter the estimates assessing the impact of decentralization on inequality. This claim is itself a testable proposition in that if decentralization is indeed endogenous to inequality, it should be found that, once the relation is specified to take this possibility into account, the impact of decentralization on inequality is substantially reduced or even ceases to be significant. From now on I shall refer to this claim as the "Endogeneity Hypothesis" (EH).

b) The very notion of two-way causality derives from the central claim of the model, namely that the institutional choice depends on the differences across regions in terms of average incomes and the incidence of individual specific risks. More specifically, it follows from the model that the greater the distance between regions in terms of income and labor market structures, the higher the levels of decentralization of redistribution, even after the relevant controls for endogeneity have been introduced. From now on, I shall refer to this claim as the "Reproduction Hypothesis" (RH), implying that in this second line of causation inequality reproduces itself by facilitating the choice of particular sets of institutions.

\section{2.- Methodological Approach}

These two hypotheses are tested against a data set of 15 OECD countries during the period 1980-1997. The hypotheses are tested separately because inequality is not measured in the same way for each of them. In EH inequality refers to the overall distribution of income and hence it is operationalized using the Gini coefficient. In the case if $\mathrm{RH}$ the structure of inequality refers to the income differential between regions in terms of average income. This is operationalized using the Between Groups share of the Theil Index (see below). Herein lies the impossibility of testing both hypotheses using one single system of equations. The methodological approach is however similar in both cases. In this section I present its main features. Thereafter, I discuss the variables used in the testing of both the EH and the RH. 
The testing of both the $\mathrm{EH}$ and the $\mathrm{RH}$ requires tackling the issue of endogeneity. In addition, the testing of the EH requires contrasting one-way against two way specifications. Thus, in this case, I first present several specifications in which a more conventional, one-way, approach is followed. In a second step, I reestimate the models implementing several techniques designed to take into account the issue of endogeneity between the left and some of the right hand side variables. For the sake of consistency, a similar strategy is followed in the case of RH. In what follows, I introduce the more conventional approaches, discuss in detail the problem of endogeneity and briefly present the features of the strategy adopted to overcome it.

By conventional approaches I refer to standard fixed and random effects estimations of the relations of interest (Greene 2000). A random effects model has the following form:

$Y_{i t}=\alpha+\beta_{1} X_{i t}+\beta_{2 \ldots n} \gamma_{i t}+\varepsilon_{i \mathrm{it}}$

where $\alpha$ represents the constant , $\boldsymbol{X}_{i t}$ represents the independent variable of interest, in this case different indicators of the structure of inequality, $\gamma_{i t}$ depicts the controlvariables, and $\varepsilon_{\text {it }}$ denotes the error term.

Alternatively, the fixed effect estimation as implemented here can be presented as follows:

$\boldsymbol{Y}_{i t}=c_{i}+\boldsymbol{t}_{i}+\beta_{1} X_{i t}+\beta_{2 \ldots n} \gamma_{i t}+\varepsilon_{t}$

where $c_{i}$ depicts a dummy variable for the cross-sectional units, and $\boldsymbol{t}_{\boldsymbol{i}}$ represents, when included, time periods dummies.

Comparative political economists disagree about the benefits of either strategy and are caught up in an ongoing lack of robustness dilemma. Random and fixed effects differ in their assumptions about the share of the variance to be exploited in order to identify the models. While the former gets all the benefits from pooling by considering the within- and the between- unit components of the variance at once, the latter freezes the between-unit component by introducing a unit dummy per cross-sectional unit. In so doing, it is concerned only with the within-unit share of the variance, in our case, the over-time behavior of the observations. Generally, fixed effects pose a harder test for any given hypothesis. They impose strong restrictions that take away the unit specific variation and, therefore, require controls 
that vary over time (otherwise there is no variance left to be accounted for). On the contrary, random effects allow for controls that do not vary over time. Table 2 includes the coefficients for the Random and the Fixed effects models in order to assess the extent to which the results are sensitive to different assumptions. In this fashion, Table 2 also includes two Tobit specifications, one with country dummies, the other without them. The inclusion of these two models addresses a potential problem of mispecification due to the fact that the dependent variable ranges between 0 and 1 . In principle, Tobit models are a special case of lower truncation in which the censor limit is set to 0 . More generally, the likelihood function can be rewritten to take into account an upper limit, in this case $1^{13}$ (Greene 2000: ch.20).

In a second step (Table 3), the models are re-specified to cope with the problem of endogeneity. There is a problem of endogeneity when "the values of our explanatory variable are sometime the consequence, rather than the cause, of our dependent variable" (King, Keohane and Verba 1994: 185; Manski 1995: 127-129). More technically, endogeneity refers to the fact that "an independent variable is potentially a choice variable, correlated with unobservables in the error term (Millimet 2001:2) ${ }^{14}$. There are several strategies to correct for this problem.

The first available solution to correct this problem is the one proposed by Baltagi (1995, 2002: 130-155), namely a two-stage least squares approach with instrumental variables. In this context the key issue in order to overcome endogeneity and properly identify the relations of interest is to find adequate instruments, i.e., "a variable that is correlated with the endogenous variable, uncorrelated with the error term and does not affect the outcome of interest conditional on the included regressors" (Millimet 2001:4). However, this solution is no panacea, for the

\footnotetext{
${ }^{13}$ In real terms, however, taking the Gini coefficient as the dependent variable, the lower limit never equals 0 (a perfectly egalitarian society) nor does the upper one equals 1 (a perfectly inegalitarian society). A more realistic specification for the OECD would be to set the truncation points at 0.20 and 0.60. The existence of an upper and a lower limit could also suggest a third alternative approach other than Tobit. Let $G$ represent the Gini Coefficient. By taking the $\log \{G / 1-G\}$, the dependent variable would range between minus infinity and plus infinity, facilitating the implementation of the standard assumptions of the regression model.

${ }^{14}$ In the real world this distinction is often subtle and complicated. Indeed the specialized literature seems to have taken a different path by establishing the conditions under which an independent variable $\mathrm{x}$ can be considered strictly exogenous in relation to $\mathrm{y}$. These are mainly two: weak exogeneity and absence of Granger causality. For a discussion on these issues see Greene (2000: 656$657)$.
} 
identification of simultaneous equation models is not straightforward (Wlezien 2002:14). In this sense, the two stage least squares approach imposes the restriction that the error terms of the n-equations included in the system are uncorrelated. Such an assumption is not necessarily reasonable ${ }^{15}$. Hence there is room to worry about the possibility of the findings obtained from the implementation of Baltagi's approach to being an artifact of a (potentially) implausible assumption. In order to rule out this possibility, an alternative way of estimating simultaneous equation models has been implemented, namely the GLS ${ }^{16}$ Zellner's Seemingly Unrelated Approach, designed specifically, in the context of simultaneous equations models, to control for contemporaneous cross-equations error correlations.

In the case of the RH a similar strategy is followed to cope with the problem of endogeneity. The dependent variable, welfare decentralization, ranges once again between 0 and 1 . In fact, for a significant number of countries, namely the most centralized ones, the value of the decentralization of redistribution is expected to be 0 . Thus a Tobit estimation is included. There is, however, one difference in the specifications selected: as ethnic fractionalization does not vary over time, it is not possible to include fixed effects.

\section{3.- Variables of Interest, Control Variables and Selection of Instruments ${ }^{17}$}

\subsection{1.- Endogeneity Hypothesis}

The testing of the EH requires assessing the role of decentralization (the variable of interest) within a more general analysis of the determinants of income inequality. Thus an indicator of overall income dispersion (the Gini coefficient for disposable income) is taken as dependent variable. In addition, the specification includes controls for the following factors: (a) political and institutional factors that

\footnotetext{
${ }^{15}$ As Eriksson has argued (1987:863-881), the higher the cross-equation error correlation, the less likely to find a proper instrument to disentangle the two-way causality. Hence the importance of making the right assumptions about the structure of the error term and implementing the appropriate specification.

${ }^{16}$ Following Greene (2000: 674-688), in presence of large cross-equation error correlations, GLS is a more efficient approach than OLS. Consequently, the larger the correlation, the larger the efficiency gains of using Zellner's approach as opposed to other approaches to simultaneous equations models.
} 
affect redistribution other than decentralization; (b) the variables conditioning the distribution of disposable income that relate to demographic processes, general economic conditions and the structure and organization of the labor market (which are known to be a major determinant of wage inequality: Rueda and Pontusson 2000: 350-383; Wallerstein 1999: 649-680); and (c) the effects of previous redistributive policies on pre-tax income inequality (Beramendi 2001).

The inclusion as explanatory variables of the incumbent's ideology and the levels of union density, together with decentralization, satisfy the controls required in (a). The specialized literature has consistently proved these two variables as major determinants of redistribution. Union density (taken as a proxy for labor power) and the incumbent's ideology capture two different dimensions of the standard "power resources approach" to the development of the welfare state ${ }^{18}$.

In turn, the introduction as control of an indicator of market income inequality provides a straightforward solution for (b) and (c). Inequalities of disposable income are a function of market income inequalities and the direct effect of redistributive policies. What is to be assessed in the different specifications is the impact of one variable that affects redistribution and, therefore, the distribution of disposable income. This goal makes the properties of an indicator of market income inequality a very useful tool. It aggregates the impact of economic, demographic and labor market related variables. More importantly, it also includes the feedback effects of previous redistributive policies on people's labor market behavior and, subsequently, on the distribution of wages and additional sources other than earnings and welfare state transfers.

Finally, as to the instruments chosen in the two-way specifications, decentralization is instrumentalized by ethnic fractionalization. This is the only variable in our dataset that bears no direct relationship with the distribution of income while being correlated with the levels of decentralization.

\footnotetext{
${ }^{17}$ The definition, construction and sources of all the variables mentioned in this section are provided in Appendix I.

${ }^{18}$ See for all Huber and Stephens (2001).
} 


\subsection{2.- Reproduction Hypothesis}

The dependent variable in this case is the degree of decentralization of redistribution, measured as the regional share of total social expenditures as reported by the IMF Government Financial Statistics (see Appendix I). As discussed above, the regional differences in terms of the structure of inequality are captured in two different ways. The first one is the coefficient of variation of regional unemployment rates in OECD countries between 1980 and $1997^{19}$. This indicator taps horizontal differences in terms of labor market structures. Since unemployment is normally associated with higher pre-tax and transfers income inequality, this indicator can also be taken as a measuring regional differences in the share of inequality due to regionally specific labor market conditions.

The second, and by far most accurate, indicator of the territorial structure of inequality consists of isolating the between groups share of total inequality by way of an income decomposition analysis in which the subnational units are the partition criteria. In this particular case, the chosen indicator is the between-group share of the Theil Index. For a limited number of measurements of inequality, it is the case that (Cowell 2000:87-150):

$\mathrm{I}(\mathrm{x}, \mathrm{y})=\mathrm{I}\left(\mathrm{x}^{*}, \mathrm{y}^{*}\right)+[\mathrm{wx}(\mathrm{I}(\mathrm{x}))+\mathrm{wy}[(\mathrm{Iy})]$

To put it differently, they are additively decomposable. The first component of this identity isolates the between group variance by holding the relevant groups in their mean, while the second component is simply a weighted sum of the variance within the two groups. What we use as a variable measuring the expression "territorial structure of inequality" is the first component of the equation above, i.e., the share of total income inequality associated to regional income differences. At this point, it is worth noting that this indicator combines information captured by the previous one in that the share of regional income variation incorporates the impact on

\footnotetext{
${ }^{19}$ Details about the sources and steps undertaken in the construction of both variables are given in the data appendix.
} 
the income distribution of the horizontal differences in terms of unemployment rates $^{20}$. Thus I do not include them together in the same specification.

Let me turn now to discuss the control variables. These include the degree of trade openness and the level of ethnic fractionalization in the society. In addition, contrary to previous specifications, I have decided not to include an indicator of aggregate national income as a control.

The absence of an aggregate indicator of national income is justified by the fact that the sample of interest is restricted to OECD economies, which, as a group, presents relatively low levels of internal variation as opposed to a sample that includes a larger number of non-OECD countries. Previous contributions on the determinants of decentralization (Panizza 1999: 97-139) have used this type of sample, and it was necessary for them to include national income as a control ${ }^{21}$.

Trade openness is conventionally measured as the sum of imports and exports as a percentage of GDP. This variable lacks a theoretical consensus in what regards its expected consequences. Some scholars (Garrett and Rodden: 2003) have argued that a higher degree of openness should be associated with higher levels of fiscal centralization because of the higher levels of exposure to international competition. To put it in terms of our model, higher degrees of openness would imply that, given that exposure to international competition and its associated risks affect all regions, the scope of risk sharing between them increases and, therefore, so do the incentives to adopt a more centralized fiscal regime. In other words, with openness, S would increase for every region. However, this is only true on the assumption that a

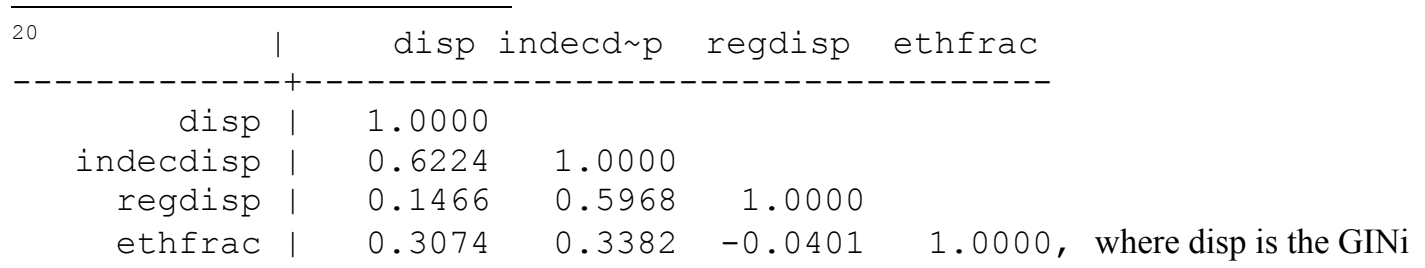
coefficient, Indecdisp is the between-group share of the Theil index, regdisp is the coefficient of variation in regional unemployment rates and Ethfrac is the index of ethnic fractionalization.

${ }^{21}$ Table 3 includes one further specification adding GDP to the set of controls. As it can be seen, the indicator of aggregate national income adds nothing to the explanation of the levels of decentralization of redistribution in the OECD. These results support the decision to exclude this variable as a control. They are also consistent with the argument by Wallis and Oates (1988:5-28) for whom the sample of countries used is crucial for the results. If the sample is reduced to developed nations, the relation 
common exposure to international competition affects all regions equally. If, on the contrary, openness generates differential effects across regions with different economic structures and risk profiles, the scope of risk sharing between regions as defined in the model would decrease. Put differently, openness could also imply bigger differences across regions in terms of their respective $\lambda$ or $\sigma$. In such a scenario, the expected relation between openness and decentralization would be positive. Since there are no major theoretical reasons to believe a priori that either of the processes dominates the other, it is not easy to derive a clear expectation about the direction of the relation. Under these circumstances the whole issue becomes an empirical question.

Finally, the inclusion of a control for ethnic fractionalization follows from the well established link between the existence of multiple cultural, linguistic and/or religious identities and the use of decentralized political arrangements to accommodate them (Linz 1997; Stepan 1997; Amoretti and Bermeo: 2003). Put briefly, decentralized/federal polities are more likely to emerge in ethnically, linguistically and/or culturally fragmented social contexts. The expected direction of the relation is clear. Notwithstanding the inherent limitations of any measurement of fractionalization, the higher its values the higher the theoretical levels of decentralization.

As to the instruments of the two-way specifications of the $\mathrm{RH}$, two variables have been chosen: an indicator of the ideology of the incumbent, shown by previous contributions to be a determinant of the degree of redistribution and, thus, of the levels of income inequality (Iversen 2001: 45-88; Huber and Stephens: 2001); and an indicator of union density, equally identified by previous contributions as a determinant of both the levels of redistribution and wage inequality (Huber and Stephens: 2001; Wallerstein 1999: 649-680; Rueda and Pontusson 2000:350-383). There are no evident theoretical reasons to expect either of them to directly affect the territorial design of redistribution. 


\section{4.- Results and Implications}

\subsection{1.- The endogeneity hypothesis.}

Tables 2 and 3 display the results regarding the EH. The inclusion of different models in each table allows us to check to what extent the results obtained are sensitive to the assumptions underpinning the different specifications adopted. In the case of the regressions in which the impact of decentralization on inequality is assumed to be exogenous (Table 2), the specifications included fixed and random effects as well as Tobit models, added to take care of the issue that the dependent variable is censored at 0 (lower limit) and 1 (upper limit). Alternatively, in those specifications where the potential problem of endogeneity is taken care of (Table 3), the models do not include fixed effects because, for some of them, the decentralization of redistribution is instrumented by ethnic fractionalization, a variable that does not vary over time.

The control variables behave in the way that is expected, with the exception of the variable measuring the incumbent's ideology. Obviously, market income inequality is a strong and consistent positive predictor of disposable income inequality. In addition, the levels of union density are, ceteris paribus, negatively correlated with the levels of disposable income inequality. On the contrary, the estimates of the variable of the incumbent's ideology are not robust, being sensitive to different specifications. Nothing can be safely concluded about this variable except for the claim that the link between the incumbent's ideology and the final outcome in terms of the distribution of income is hard to tap in the context of a regression analysis. 
Table 2.- The Impact of Decentralization on Inequality I

\begin{tabular}{|c|c|c|c|c|}
\hline & \multicolumn{4}{|c|}{ MODELS ASSUMING AN EXOGENOUS EFFECT } \\
\hline & Model A & Model B & Model C & Model D \\
\hline $\begin{array}{l}\text { Welfare } \\
\text { Decentralization }\end{array}$ & $\begin{array}{l}0.1652 * * * \\
(0.006)\end{array}$ & $\begin{array}{l}0.1913 * * * \\
(0.0113)\end{array}$ & $\begin{array}{l}0.129 * * * \\
(0.010)\end{array}$ & $\begin{array}{l}0.191 * * \\
(0.10)\end{array}$ \\
\hline $\begin{array}{l}\text { Union } \\
\text { Density }\end{array}$ & $\begin{array}{l}-0.0009 * * * \\
(0.00004)\end{array}$ & $\begin{array}{l}-0.0007611 * * * \\
(0.000290)\end{array}$ & $\begin{array}{l}-0.00094 * * * \\
(0.000038)\end{array}$ & $\begin{array}{l}-0.00076 * * * \\
(0.00028)\end{array}$ \\
\hline $\begin{array}{l}\text { Incumbent's } \\
\text { Ideology }\end{array}$ & $\begin{array}{l}-0.00005 * \\
(0.00002)\end{array}$ & $\begin{array}{l}-0.0000246 \\
(0.0000191)\end{array}$ & $\begin{array}{l}-\mathbf{0 . 0 0 0 0 0 8} \\
(\mathbf{0 . 0 0 0 0 1 8 6 )}\end{array}$ & $\begin{array}{l}-0.000024 \\
(0.000023)\end{array}$ \\
\hline $\begin{array}{l}\text { Market Income } \\
\text { Inequality }\end{array}$ & $\begin{array}{l}0.7534 * * * \\
(0.0351)\end{array}$ & $\begin{array}{l}0.441 * * * \\
(0.042)\end{array}$ & $\begin{array}{l}0.722 * * * \\
(0.0103)\end{array}$ & $\begin{array}{l}0.441 * * * \\
(0.047)\end{array}$ \\
\hline $\begin{array}{l}\text { R-Squared/Log } \\
\text { Likelihood }\end{array}$ & 0.796 & 0.964 & 457.779 & 509.864 \\
\hline
\end{tabular}

Standard Errors in Parenthesis. Model A: Random Effects. Model B: Fixed Effects. Panel Corrected Standard Errors. Model C: Tobit estimation excluding country dummies. Model D:Tobit estimation including country dummies.

Table 3.- The Impact of Decentralization on Inequality II

\begin{tabular}{|c|c|c|}
\hline & \multicolumn{2}{|c|}{$\begin{array}{l}\text { MODELS CONTROLLING FOR } \\
\text { ENDOGENEITY }\end{array}$} \\
\hline & Model A & Model C \\
\hline $\begin{array}{l}\text { Welfare } \\
\text { Decentralization }\end{array}$ & $\begin{array}{l}\mathbf{0 . 0 8 1 7 7} \\
(\mathbf{0 . 0 6 6 4 )}\end{array}$ & $\begin{array}{l}0.0298 * \\
(0.0178)\end{array}$ \\
\hline $\begin{array}{l}\text { Union } \\
\text { Density }\end{array}$ & $-0.00127(0.00028) * * *$ & $\begin{array}{l}-0.00090 * * * \\
(0.00008)\end{array}$ \\
\hline $\begin{array}{l}\text { Incumbent's } \\
\text { Ideology }\end{array}$ & $\begin{array}{l}-0.000027 \\
(0.000026)\end{array}$ & $\begin{array}{l}-0.000056 \\
(0.00004)\end{array}$ \\
\hline $\begin{array}{l}\text { Market Income } \\
\text { Inequality }\end{array}$ & $\begin{array}{l}0.3835 * * * \\
(\mathbf{0 . 0 6 1 2})\end{array}$ & $\begin{array}{l}0.7415 * * * \\
(0.052)\end{array}$ \\
\hline R-Squared & 0.6463 & 0.795 \\
\hline
\end{tabular}

Standard Errors in Parenthesis. Model A: Two-Stages least Square Instrumental Variable Estimation. Decentralization is instrumented by ethnic fractionalization. Model B: Path Analysis in Structural form. Model B: Seemingly Unrelated Regression (SUR) estimation.

This is the case mainly because governments' policy choices potentially affecting the distribution of income are multidimensional (several effects may be working in 
opposite directions) and complex enough to escape a single scale (for instance, conservative central European governments put a lot more effort into transfers than into services, which in pure income terms may make them appear fairly redistributive).

The test of the EH was set as a comparison of the role of the variable measuring the decentralization of redistribution under two types of econometric specifications, namely a group of models that assume the impact of decentralization to be exogenous and a second group in which the relation is specified controlling the bidirectional nature of the relation between decentralization and inequality. $\mathrm{EH}$ is supported by the results. After controlling for endogeneity, only the estimates obtained in the seemingly unrelated regression remain significant at the $90 \%$ confidence level. Moreover, they become substantially smaller than the ones produced by any of the models reported in Table 2 .

The confirmation of the endogeneity hypothesis makes clear that a large share of the inegalitarian effect conventionally attributed to decentralization is due to a problem of reverse causality in the specifications. Yet new questions arise. According to some of the models in Table 3, it could be argued that the relation between decentralization and inequality is not a bidirectional relation whose different sequences are analyzable in their own right, but rather a one way relation that, in order to be understood, must be turned upside down. Former contributions would have gotten the direction wrong, but the relation would still be mono-directional. Such an interpretation would go beyond the results reported in Tables 2 and 3. Let me briefly address why.

In the event of a change towards decentralization, a number of different political processes are activated in each of the units as well as in the union as a whole. Some regions, as argued above, may decide to increase redistribution while some others may choose otherwise. These choices are facilitated by decentralization itself and they channel its distributive effects. The problem is that these decisions may work in different ways; and depending upon how they get combined they may or may not be reflected by a regression coefficient. If all the units in one country follow a similar pattern (say reduction of redistribution, increase in inequality), it is 
likely that in this country the association between decentralization and inequality will gain in strength. As long as a similar process takes place in a large enough number of countries, a significant regression coefficient will emerge even after the appropriate controls and specifications are adopted. If, on the contrary, decentralization makes units follow different strategies, the distributive effects of the unit's choices may cancel each other out. If this pattern is frequent enough, the coefficient in the regression is likely to be insignificant. But this by no means implies that decentralization has no distributive consequences. It simply suggests that regression analysis may not be the optimal tool to capture them.

\subsection{2.- The Reproduction Hypothesis}

Table 4 reports the findings concerning the RH. Trade openness shows positive and significant effects, generally very small, in all fixed and random effects estimations, except for the one in which the structure of inequality is measured as the between groups share of the Theil index. This suggests that among the two possible effects inherent to higher levels of openness discussed in the previous section, the one enhancing economic specialization dominates the one leading to a converging increase in region specific risks (S). However, given the nature of the data, the fact that the variable is not consistently significant across all specifications and the fact that previous contributions have come to different conclusions (Garrett and Rodden: 2003), any conclusion to be derived from this variable should be treated with a great deal of cautiousness ${ }^{22}$.

\footnotetext{
22 The process of European Integration and its interaction with the way of measuring "trade-openness" may shed some light on why the results of this chapter differ from the ones in previous contributions. The EU has undoubtedly raised openness but, at the same time, it may have also reduced risks for its constituent units. Given the large number of OECD countries that actually belong to the EU, such process may account for the fact that, concerning the direction of the effect, trade openness emerges as a factor enhancing the decentralization of social expenditures. By insuring against region-specific risks, the EU would be reducing the potential costs in which the Member States would incur in case they decided to decentralize redistribution.
} 
Table 4.- Testing the Reproduction Hypothesis (Standard Errors in Parentheses).

\begin{tabular}{|c|c|c|c|c|c|c|c|}
\hline & \multicolumn{7}{|c|}{ WELFARE DECENTRALIZATION (1980-1997) } \\
\hline & Model A & Model B & Model C & Model D & Model E & Model F & Model G \\
\hline $\begin{array}{l}\text { Unemployment } \\
\text { Regional Disparities }\end{array}$ & $\begin{array}{l}0,1339 * * \\
(\mathbf{0 , 0 5 6 )}\end{array}$ & \begin{tabular}{|l|}
0.0844 \\
$(0.064)$ \\
\end{tabular} & $\mid-------$ & |-------- & ----- & ----- & $\mid----$ \\
\hline $\begin{array}{l}\text { Between-Group Share of } \\
\text { the Theil Index }\end{array}$ & |---------- & $\begin{array}{l}0,0231 * * * \\
(0,0047)\end{array}$ & $\begin{array}{l}0.029 * * * \\
(0.010)\end{array}$ & $\begin{array}{l}0.0187 * * * \\
(0.0040)\end{array}$ & $\begin{array}{l}0.0990 * * * \\
(0.0027)\end{array}$ & $0.042 * * *$ & $0.035 * * *$ \\
\hline Ethnic Fractionalization & $\begin{array}{l}0.229 * * * \\
(0.025)\end{array}$ & $\begin{array}{l}0.232 * * * \\
(0,028)\end{array}$ & $\begin{array}{l}0.1731 * * \\
(0.095)\end{array}$ & $\begin{array}{l}0.227 * * * \\
(0.028)\end{array}$ & $\begin{array}{l}0.099 * * * \\
(0.028)\end{array}$ & $0.0719 * *$ & $0.192 * * *$ \\
\hline Openness & $\begin{array}{l}0.00069 * * \\
(0.00024)\end{array}$ & $\begin{array}{l}0,00059 * * \\
(0.00021)\end{array}$ & \begin{tabular}{|l|}
0.0028 \\
$(0.0030)$
\end{tabular} & $\begin{array}{l}0.011 * * * \\
(0.0033)\end{array}$ & $\begin{array}{l}0.00066 \\
(0.00086)\end{array}$ & 0.0012 & $0.003 * *$ \\
\hline GDP & ------ & |--------- & |------- & |------- & |--------- & $-2.88 e-08$ & $-9.33 e-09$ \\
\hline $\begin{array}{l}\text { R-Squared/Log- } \\
\text { likelihood (N) }\end{array}$ & $\begin{array}{l}0.4213 \\
(121)\end{array}$ & $\begin{array}{l}0.5229 \\
(121)\end{array}$ & $0.4619121)$ & $\begin{array}{l}0.5351 \\
(121)\end{array}$ & $\begin{array}{l}2011.4 \\
(121)\end{array}$ & $\begin{array}{l}0.527 \\
(121)\end{array}$ & $\begin{array}{l}0.552 \\
(121)\end{array}$ \\
\hline
\end{tabular}

Model A.-. Models A and B: Simultaneous equations models. Seemingly Unrelated Regressions Model C.- Two Steps GLS instrumental variable estimation. Random Effects. The Instruments for inequality are Union Density and Government Ideology . Model D.- Simultaneous equations models. Seemingly Unrelated Regressions. Model E.- Tobit Random Effects. Model F.- Two-Stage least squares instrumental variables estimation. Model G.- Simultaneous Equations Models. Seemingly Unrelated Regressions. 
The effect of ethnic fractionalization is more consistent across the models, working in the expected direction and consistently with the previous literature (Panizza 1999: 97-139).Let me turn now to discuss the variables of interest.

Of the two variables of interest, the coefficient of variation of regional unemployment rates shows significant effects on the degree of decentralization of redistribution, albeit only on its own (Models A and B, Table 4$)^{23}$. In turn, the impact of the between groups share of the Theil Index supports the predictions of the model, showing a positive relation with the degree of decentralization of redistribution that remains significant across specifications. As in the case of $\mathrm{EH}, \mathrm{RH}$ receives support from the data analysis. The structure of inequality shapes the degree of decentralization. The question remains though as to what the real magnitude of these effects is. In order to answer this question, the predicted values of Model B in Table 4 are analyzed.

Graph 1 represents the impact of the between-group share of the Theil Index as it goes from its minimum to its maximum value, when ethnic fractionalization itself is at its minimum, its mean and its maximum and trade openness is kept at its mean. The y axis depicts the regional share of social expenditures whilst the $\mathrm{x}$ axis represents the values of the independent variable of interests at its minimum, its mean and its maximum. Recall, for the purposes of interpretation, that the share of regional social expenditures goes from 0 to 1.

\footnotetext{
${ }^{23}$ Once it is included together with the between groups share of the Theil Index, its effect vanishes. This points to the fact, discussed above, that both variables overlap. Because the between groups share of the Theil Index also reflects differences due to the incidence of unemployment, the two dimensions of the model (income and risks) are not perfectly isolatable given the data available.
} 


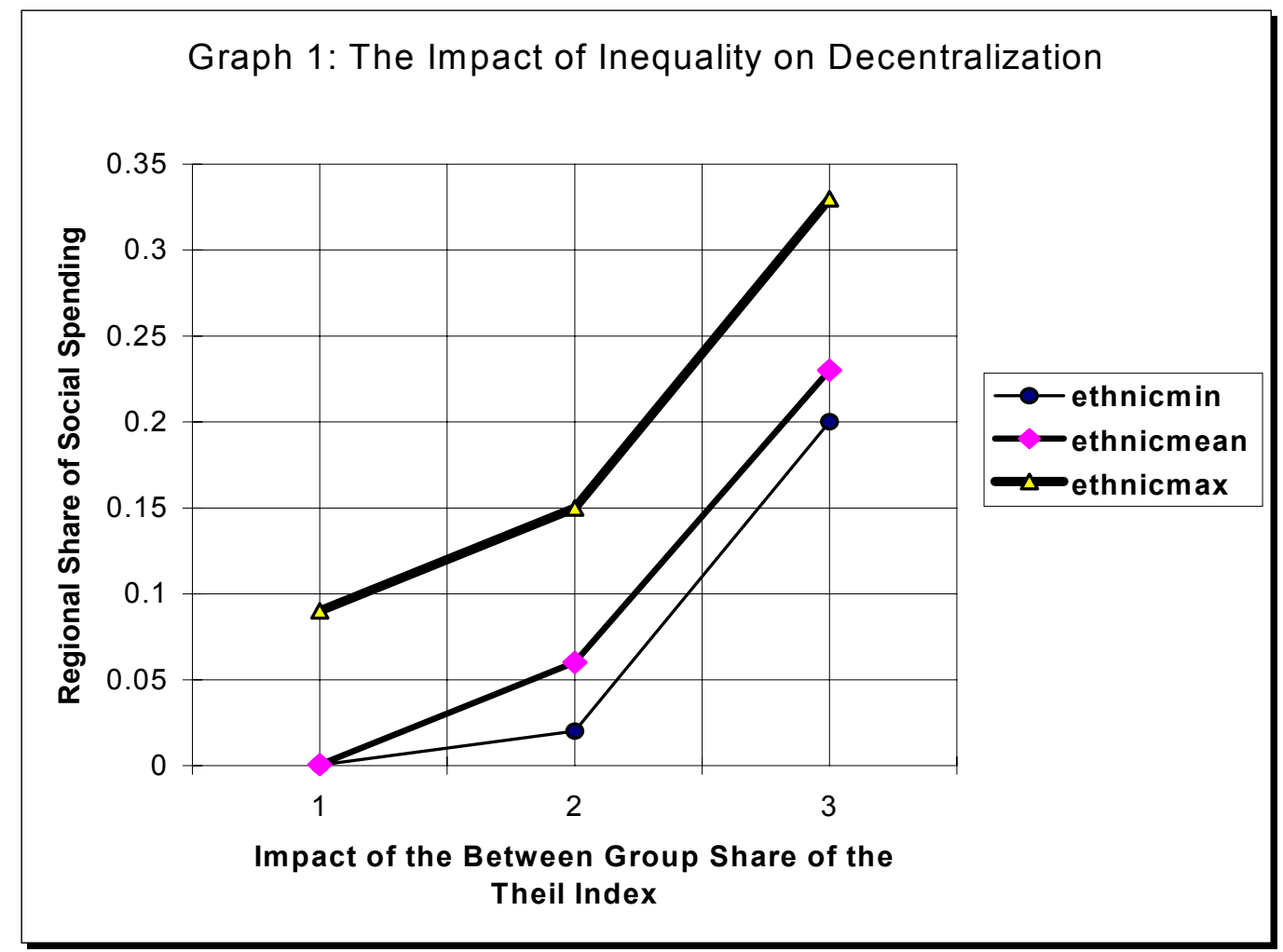

It is clear from Graph 1 that the level of ethnic fractionalization has a huge impact in predicting the levels of decentralization, as represented by the gap between the "-mean" and "-max" series. For any given value of the independent variables of interest, a change from the mean to the maximum value of ethnic fractionalization implies an increase in the regional share of social expenditures that ranges between 9 and 16 percent points. As far as the between groups share of the Theil Index is concerned, a change from its minimum to its maximum value implies that the regional share of social expenditures increases by 19, 22 and 24 percentage points provided that ethnic fractionalization is, respectively, at its minimum, mean and maximum value. Ceteris paribus, larger regional income disparities imply more decentralization of redistribution.

Graphs 2 and 3 exploit the time dimension of the data. An even more intuitive picture of the impact of the structure of inequality on the design of redistribution emerges from depicting by how much the regional share of social expenditures in any given country $\mathrm{X}$ changes over time if its structure of inequality happened to follow the pattern existing in any other nation. Graphs 2 to 4 perform this exercise for a number of countries included in the sample, namely the UK (Graph 2), Belgium 
(Graph 3) and Canada (Graph 4). In each of them the actual regional share of social expenditures is compared to a simulated share. The simulated shares are depicted for each Graph under the heading "as cname", where cname represents the country whose regional income disparities (Theil index) are taken to simulate, given the parameters of the model and leaving all the other variables in their actual value over time, the alternative predictions. The difference between the actual share of the country and the simulated ones taps the magnitude of the impact of the betweengroup share of the Theil Index on the regional share of social expenditures over time.

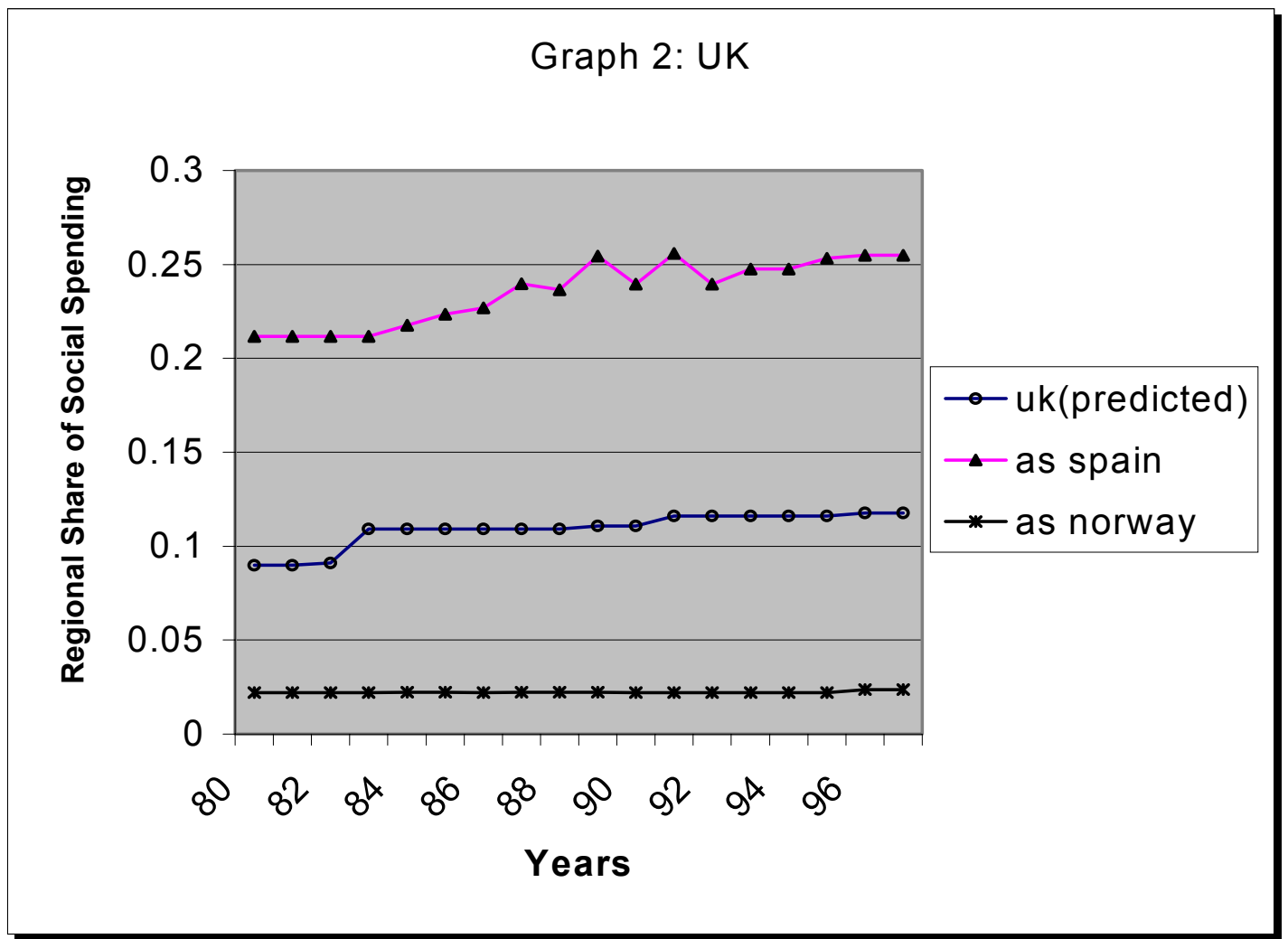



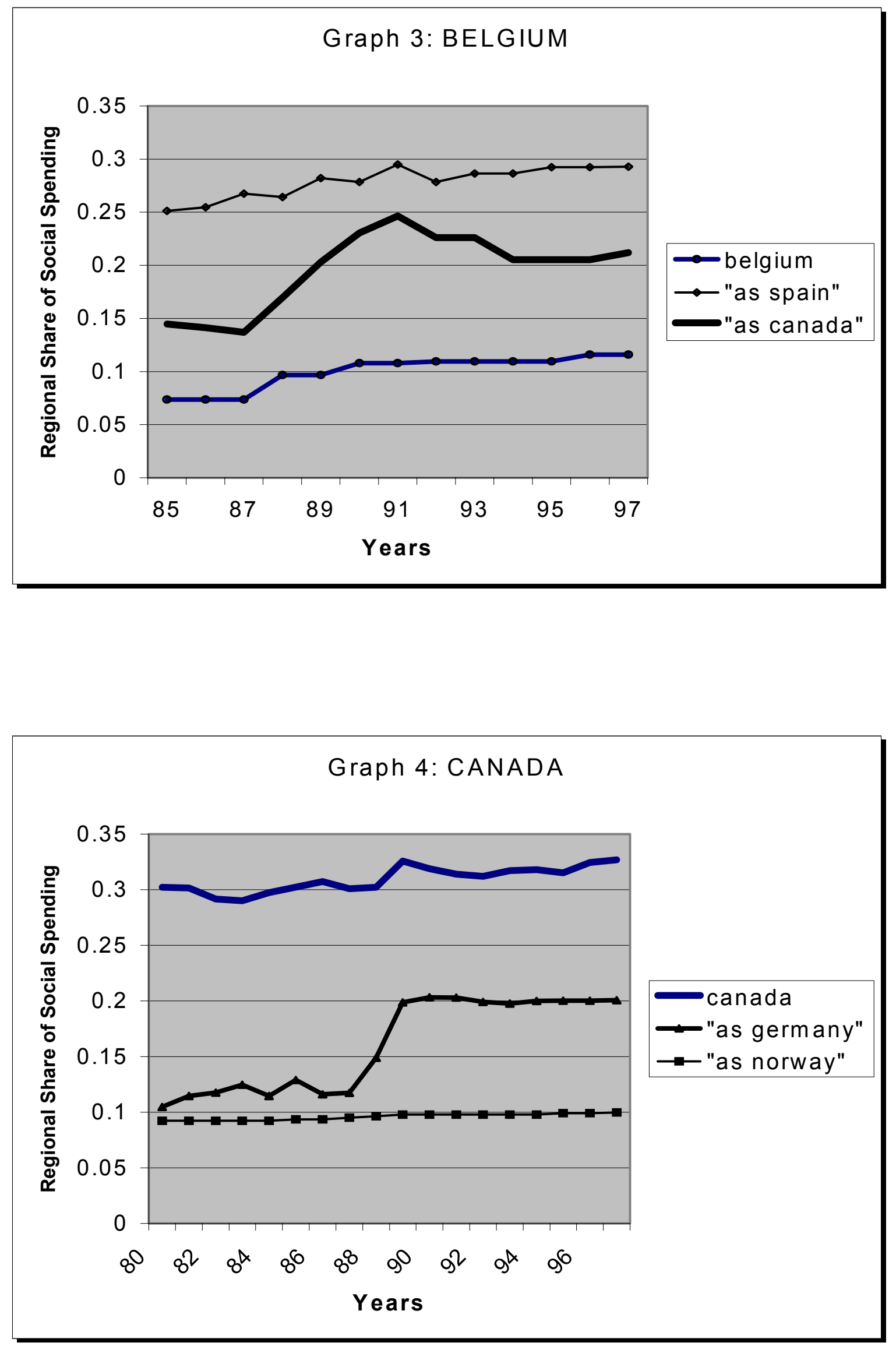
The resulting picture is of great interest in that the between groups share of the Theil Index emerges as the major determinant of the regional share of social expenditures. For instance, if the levels of regional disparities in the UK resembled the Spanish ones (Graph 2), its regional share of social expenditures would go from $11 \%$ (in this case, the predicted level with all the UK variables in the model) to $25 \%$ over a period of 15 years. An even bigger increase, from 11 to $30 \%$, would take place in the event of Belgium having the Canadian structure of inequality (Graph 3). Finally, if Canada resembled Germany its share would have dropped from 30\% to $13-10 \%$ during the 1980 s, but only from 32 to $20 \%$ during the 1990 s due to the change in trend imposed by the Reunification (Graph 4). In sum, these graphs show the extent to which the regional differences in terms of average income are the driving force of the decentralization of redistribution, supporting the predictions of the model. 


\section{4.- Conclusion}

Decentralization of political authority has become increasingly common over the last decades. This paper has analyzed its interplay with the politics of inequality and redistribution. The conventional approach to the topic has been to argue that decentralization causes higher levels of inequality, either by facilitating vetos towards redistribution or by setting the stage for a race to the bottom (Huber et al. 1993; Peterson and Rom 1990; Peterson 1995; Proud'homme 1995; Lane and Ersson 2000). Thus the often observed association between decentralization and inequality is explained as the result of an exogenous effect of the former on the latter.

The results of this paper challenge this line of argument as incomplete and potentially misleading. Specifically, I have argued that decentralization has distributive consequences that are contingent upon the existing structure of inequality. Because of such contingency, actors anticipate the distributive effects of different institutional designs and, thereby, inequality becomes a determinant of the institutional choice. The paper has been able to show empirically that such institutional choice reflects to a large extent the existing structure of inequality. In other words, decentralization is indeed endogenous with respect to the territorial component of the distribution of income.

These conclusions on the particular case of decentralization point to the convenience of a more general revision of the current understanding of the relation between political institutions and social outcomes. Observed associations may well be reflecting processes of historical self-selection, rather than exogenous effects, in many other realms. 


\section{APPENDIX I: VARIABLES DESCRIPTION AND SOURCES}

The purpose of this Data Appendix is to present the sources and to describe the construction of the variables used in the statistical analyses carried out in the paper. With varying degrees of incidence of missing values across the variables, the dataset contains information for the period 1980-1997 for 15 OECD countries ${ }^{24}$. The Variables are presented in alphabetical order.

\section{Between-Group Share of the Theil Index.}

Variable constructed by the author. The Theil Index is part of a family of measurements of inequality called single parameter Generalized Entropy class GE $(\alpha)$, for $\alpha=-1,0,1,2$. The more positive $\alpha$ is, the more sensitive $\operatorname{GE}(\alpha)$ is to income differences at the top of the distribution; the more negative $\alpha$ is, the more sensitive it is to differences at the bottom of the distribution. $\mathrm{GE}(0)$ is the mean logarithmic deviation, GE(1) is the Theil Index, and GE(2) is half the square of the coefficient of variation. The values of the GE measures vary between 0 and $\infty$, with 0 representing an equal distribution and higher values representing higher levels of inequality. In addition to satisfying the standard properties of inequality measures (namely, Mean Independence, Population Size Independence, Symmetry and the Pigou-Dalton Transfer sensitivity), the Theil Index is characterized by the fact that it is additively decomposable, as explained in the text. More formally, the measurements of inequality that belong to the Generalized Entropy class are given by:

$$
G E(\alpha)=\frac{1}{\alpha^{2}-\alpha}\left[\frac{1}{n} \sum_{i=1}^{n}\left(\frac{y_{i}}{\bar{y}}\right)^{\alpha}-1\right]
$$

And more specifically, for $\alpha=1$, the Theil Index is given by:

$$
G E(1)=\frac{1}{n} \sum_{i=1}^{n}\left(\frac{y_{i}}{\bar{y}}\right) \cdot \ln \left(\frac{y_{i}}{\bar{y}}\right),
$$

where the first term represents the weight, i.e., the share of aggregate income of the group(s) of interest, in this case regions, and the second term represents the income of the individual relative to the mean. This means that the Theil Index is a weighted geometric average of the income relatives. See Beramendi (2003) for a more detailed description of the calculation procedures.

\section{Coefficient of Variation in Regional Unemployment Rates.}

Variable constructed by the author. By regional it is meant a level of government similar to the German or Austrian Länder, the Canadian Provinces, the American States, the Spanish Comunidades Autonomas, the French or Italian regions

${ }^{24}$ These countries are: Australia, Belgium, Canada, Denmark, Finland, France, Germany, Italy, Japan, Netherlands, Norway, Spain, Sweden, UK and USA. 
or, if not self-evident, their closest administrative equivalent available, as in the case of Scandinavian nations. Sources: EUROSTAT-New Cronos Database (NUTS-3 regions); and estimates obtained from the labor force surveys (various years) run by the following statistical offices: Statistics Canada; Bureau of the Census; Australian Bureau of Statistics; Statistics Finland; Statistics Norway; Statistics Denmark; Statistics Sweden. See Beramendi (2003) for a list of the administrative division available in the case of Scandinavian nations.

\section{Decentralization of Redistribution.}

Variables constructed by the author. The IMF Yearbooks of Government Financial Statistics (1975-1999) provide the raw material for the construction of a number of indicators measuring the proportion of revenues and expenditures in the hands of the different levels of government. In fact, as to expenditures, they do even collect data about their allocation by function and level of government. On the basis of these data, the decentralization of redistribution is defined as the regional share of total social expenditures.

\section{Ethnic Fractionalization.}

From all the alternatives available in the literature (Laitin 2000: 142-155) I have, conventionally, adopted the one that measures ethnic fractionalization as one minus the sum of squared population proportions in each "ethnolinguistic" group, where the groups were originally defined according to the 1960 Soviet Ethnographic Atlas. The final figure represents the probability that two people drawn randomly are from a different ethnic group since the sum of squared population proportions is the probability that two random people are from the same group.

\section{Government Partisanship}

This is an index of the partisan left/right "center of gravity" developed by Cusack (1997) . It is based on Castles and Mair' s (1984) coding of government parties' placement on a left right scale, weighted by the decimal share of cabinet portfolios.

The variable ranges from 0 (extreme right) to 4 (extreme left).

\section{Market and Disposable Income Inequality: Gini Coefficient}

Variables constructed by the author. The Gini Coefficient ranges between 0 (perfectly egalitarian society) and 1 (perfectly inegalitarian society). The Gini coefficient is based on the Lorenz curve, a cumulative frequency curve that compares the distribution of a specific variable (income) with the uniform distribution that represents equality (in this case, the $45^{\circ}$ line). Intuitively, in order to obtain the Gini coefficient, graph the cumulative percentage of households (from poor to rich) on the $\mathrm{X}$ axis and the cumulative percentage of income on the $\mathrm{Y}$ axis. In this way, the Lorenz curve is obtained. The Gini coefficient is simply the ratio between the area of the distribution between the $45^{\circ}$ line and the Lorenz curve on the one hand and the total area of the distribution on the other. More formally, the Gini coefficient is given by

$$
\text { Gini }=\frac{1}{2 n(n-1) \bar{y}} \sum_{i=1}^{n} \sum_{j=1}^{n}\left|y_{i}-y_{j}\right|
$$


which represents the average absolute distance between any two individuals randomly selected. The Gini is calculated for the two following income concepts:

Market $=$ GWS + SEI + CPI, where GWS stands for gross wages and salaries (earnings), SEI stands for self-employment income and CPI refers to cash property income.

Disposable $=$ Market + TR $-\mathrm{TX}$, where TR is the sum of all transfers received by the working age population and TX stands for the sum of social security contributions and income tax.

Only the working age population is considered, i.e., only people aged 16 to 59 are included. The following equivalence scale has been used: $\left(1+\mathrm{CH}^{*} 0.3+(\mathrm{N}-\right.$ $\left.\mathrm{CH}-1)^{*} 0.4\right) / 1.7$, where $\mathrm{N}$ represents the number of people in the household and $\mathrm{CH}$ the number of children under 18. See Beramendi (2003) for a more detailed explanation of the calculation procedures.

GDP: Real GDP per capita in 1985 US\$. Source: Penn World Tables. (http://pwt.econ.upenn.edu).

Trade Openness. It is defined as the sum of total imports and exports on good and services as a percentage of GDP. Source: OECD, National Accounts, Part II: Detailed Tables (various years).

\section{Union Density}

The variable measures employed union members as a percentage of the employed labor force. The variable is available in the Huber, Ragin and Stephens (1997) Comparative Welfare States Data Set, Northwestern University and University of North Carolina. Original data come from Visser J. (1989, 1996). 


\section{References}

Alesina, A, and Perotti, R. 1998. "Economic Risks and Political Risks in Fiscal Unions”, The Economic Journal, 108: 989-1008.

Alesina, A., Angeloni, I. and Etro, F. 2001. The Political Economy of International Unions, manuscript, October.

Amoretti, U. and Bermeo, N. 2003. Federalism, Unitarism and Territorial Cleavages, John Hopkins University Press, forthcoming.

Atkinson, A.B. 1995. Incomes and the Welfare State, Cambridge University Press

Baltagi, B . 1995. Econometric Analysis of Panel Data, New York, John Wiley .

Beramendi-Alvarez P. 2001. The Politics of Income Inequality: the Role of Second Order Effects, Luxembourg Income Study, Working-Paper Series, 284.

Beramendi-Alvarez P. 2003. Decentralization and Income Inequality, Juan March Institute, Madrid.

Boadway, R. 2001. The Imperative of Fiscal Sharing Transfers, UNESCO

Bolton, P. and Roland, G. 1996. "Distributional Conflicts, Factor Mobility and Political Integration", American Economic Associations Papers and Proceedings, 86(2): 99-104.

Bolton, P. and Roland, G. 1997. "The Breakup of Nations: a Political Economy Analysis", Quarterly Journal of Economics, 112: 1057-1090.

Bolton, P., Roland, G. and Spolaore, E. 1996. "Economic Theories of the Break-up and Integration of Nations", European Economic Review, 40: 697-705.

Buchanan, J. 1950. "Federalism and Fiscal Equity", American Economic Review, 40: 583-599.

Castles, F. and Mair, P. 1984. "Left-right Political Scales: some "expert" judgements", European Journal of Political Research, 12: 73-88.

Cowell, F. 2000. "Measurement of Inequality", in Atkinson, A.B. and Bourguignon, F. (eds.), Handbook of Income Distribution, Oxford, Elsevier.

Cremer, H., et al. 1997. "Income Redistribution in an Economic Union: the Trade off between Inter and Intra-national Redistribution", International Tax and Public Finance, 4: 325-335.

Cusack, T. R. 1997. "Partisan Politics and Public Finance: Changes in Public Spending in the Industrialized Democracies, 1955-1989", Public Choice, 91: 375395. 
Elazar, D. 1994. Federal Systems of the World. London. Longman Group.

Eriksson, R. 1987. "The "Uncorrelated Errors" Approach to the Problem of Causal Feedback", Journal of Politics, 44: 863-881.

Estevez-Abe, M., Iversen, T. and Soskice, D. 2001. "Social Protection and the Formation of Skills: a Reinterpretation of the Welfare State" in Hall, P. and Soskice, D. (eds.) Varieties of Capitalism, Oxford, Oxford University Press.

Garrett, G. and Rodden, J. 2003. "Globalization and Fiscal Decentralization", in Miles Kahler and David Lake (eds.) Globalizing Authority, Princeton, Princeton University Press, forthcoming.

Greene, W. 2000. Econometric Analysis, Prentice Hall.

Huber, Evelyne, Ragin, Charles and Stephens, John D. 1993. "Social Demoracy, Christian Democracy, Constitutional Structure and the Welfare State", American Journal of Sociology 99(3): 711-750.

Huber, Evelyne, Ragin, Charles and Stephens, John D. 1997. Comparative Welfare States Data Set, Norhtwestern University and University of North Carolina.

Huber, Evelyne and Stephens, John D. 2001. Development and Crisis of the Welfare State, Chicago, The University of Chicago Press.

Iversen, Torben. 2001. "The Dynamics of Welfare State Expansion: Trade Openness, Deindustrialization and Partisan Politics" in Pierson, P. (ed.), The New Politics of the Welfare State, Oxford, Oxford University Press.

Iversen, Torben and Soskice, D. 2001. "An Asset Theory of Social Policy Preferences”, American Political Science Review, 95(4): 875-895.

King, Gary, Keohane, Robert and Verba, Sidney, 1994. Designing Social Inquiry, Princeton, Princeton University Press.

Lane, Jan-Erik and Ersson, Svante, 2000. "Althusius" in The new institutional politics : performance and outcomes, New York, Routledge.

Linz, J. 1997. Democracy, Multinationalism and Federalism, CEACS WP, IJM, 103.

Manski, Charles F. 1995. Identification Problems in the Social Sciences, Cambridge Ma., Harvard University Press.

Mares, I. 2001. "Firms and the Welfare State: When, Why and How does Social Policy matter to Employers?" in Hall, P. and Soskice, D. (eds.), Varieties of Capitalism, Oxford, Oxford University Press.

Meltzer, A. H. and Richard, S., F. 1981. "A Rational Theory of the Size of Government", Journal of Political Economy, 89: 914-927. 
Millimet, D. 2001. "What is the difference between "endogeneity" and "sample selection bias?" mimeo.

Oates, W. 1999. “An Essay on Fiscal Federalism”, Journal of Economic Literature, XXXVII : 1120-1149.

OECD 1997. Managing across levels of Government. Paris

Panizza, U. 1999. "On the determinants of fiscal centralization: theory and evidence”, Journal of Public Economics, 74: 97-139.

Persson, T. and Tabellini, G. 1994. "Does Decentralization increase the size of Government?", European Economic Review, 38: 765-773.

Persson, T. and Tabellini, G. 1996a. "Federal Fiscal Constitutions: Risk Sharing and Redistribution", Journal of Political Economy, 104(5): 979-1009.

Persson, T. and Tabellini, G. 1996b. "Federal Fiscal Constitutions: Risk Sharing and Moral Hazard”, Econometrica, 64(3): 623-646.

Persson; T. and Tabellini; G. 2000. Political Economics. Explaining Economic Policy, London, MIT Press.

Peterson, P. and. Rom, M. 1990. Welfare Magnets. A New Case for a National Standard, Washington D.C., The Brookings Institution.

Peterson, P. 1995. The Price of Federalism, Washington D.C., The Brookings Institution.

Pierson P. 2001 (ed.). The New Politics of the Welfare State, Oxford, Oxford University Press.

Prud'homme, R. 1995: “ The Dangers of Decentralization”, The World Bank Research Observer, 10(2): 201-220.

Roberts, K. 1977. "Voting over Income Tax Schedules", Journal of Public Economics, 8, : 329-340.

Romer, T. 1975. "Individual Welfare, Majority Voting and the Properties of a Linear Income Tax", Journal of Public Economics, 4(2): 163-185.

Rose-Ackerman, S. 1981. "Does Federalism Matter? Political Choice in a Federal Republic", Journal of Political Economy, 89(11): 152-165.

Rueda, D. and Pontusson, J. 2000. "Wage Inequality and Varieties of Capitalism", World Politics, 52 (3): 350-383. 
Sinn, H.W. 1995. "A Theory of the Welfare State", Scandinavian Journal of Economics, 97(4): 495-526.

Stepan, A. 1997. Toward a New Comparative Analysis of Democracy and Federalism: Demos Constraining and Demos Enabling Federations, Paper presented in the panel "Federalism and Democracy: Comparative Questions" IPSA Meetings, Seul, Korea.

Varian, H. 1980. "Redistributive Taxation as Social Insurance", Journal of Public Economics, 14: 49-67.

Visser, Jelle. 1989. European Trade Unions in Figures. Deventer/Netherlands: Kluwer Law and Taxation Publishers

Visser, Jelle. 1996: Unionization Trends: The OECD Countries Membership File, CESAR, University of Amsterdam.

Wallerstein, M. 1999. "Wage-Setting Institutions and Pay Inequality in Advanced Industrial Societies", American Journal of Political Science, 43(3): 649-680.

Wallis, J. and Oates, W. 1988. "Decentralization in the Public Sector: an empirical study of State and Local Government" in Rosen, H. (ed.) Fiscal Federalism: Quantitative Studies, Chicago, University of Chicago Press.

Wildasin, D. 1995. "Factor Mobility, Risk and Redistribution in the Welfare State", Scandinavian Journal of Economics, 97: 527-546.

Wlezien, C. 2002. A Note on the Endogeneity of Ideological Placements of Governmental Institutions, Nuffield College, Politcs Group, Working Papers Series $\# 16$.

Wright, V. and Hesse, J.J. (eds.) 1996. Federalizing Europe?, Oxford, Oxford University Press. 


\section{Bücher des Forschungsschwerpunkts Markt und politische Ökonomie Books of the Research Area Markets and Political Economy}

Andreas Stephan

Essays on the Contribution of Public Infrastruc-ture to Private: Production and its Political Economy

2002, dissertation.de

Hans Mewis

Essays on Herd Behavior and Strategic

Delegation

2001, Shaker Verlag

Andreas Moerke

Organisationslernen über Netzwerke - Die personellen Verflechtungen von Führungsgremien japanischer Aktiengesellschaften

2001, Deutscher Universitäts-Verlag

Silke Neubauer

Multimarket Contact and Organizational Design

2001, Deutscher Universitäts-Verlag

Lars-Hendrik Röller, Christian Wey (Eds.)

Die Soziale Marktwirtschaft in der neuen

Weltwirtschaft, WZB Jahrbuch 2001

2001, edition sigma

Michael Tröge

Competition in Credit Markets: A Theoretic

Analysis

2001, Deutscher Universitäts-Verlag

Tobias Miarka

Financial Intermediation and Deregulation:

A Critical Analysis of Japanese Bank-Firm-

Relationships

2000, Physica-Verlag

Rita Zobel

Beschäftigungsveränderungen und organisationales

Lernen in japanischen Industriengesellschaften

2000, Humboldt-Universität zu Berlin

http://dochost.rz.hu-berlin.de/dissertationen/zobel-rita-

2000-06-19

Jos Jansen

Essays on Incentives in Regulation and Innovation

2000, Tilburg University

Ralph Siebert

Innovation, Research Joint Ventures, and

Multiproduct Competition

2000, Humboldt-Universität zu Berlin

http://dochost.rz.hu-berlin.de/dissertationen/siebert-

ralph-2000-03-23/

Damien J. Neven, Lars-Hendrik Röller (Eds.)

The Political Economy of Industrial Policy in Europe and the Member States

2000 , edition sigma
Jianping Yang

Bankbeziehungen deutscher Unternehmen: Investitionsverhalten und Risikoanalyse

2000, Deutscher Universitäts-Verlag

Christoph Schenk

Cooperation between Competitors - Subcontracting and the Influence of Information, Production and Capacity on Market Structure and Competition 1999, Humboldt-Universität zu Berlin http://dochost.rz.hu-berlin.de/dissertationen/schenkchristoph-1999-11-16

Horst Albach, Ulrike Görtzen, Rita Zobel (Eds.) Information Processing as a Competitive Advantage of Japanese Firms

1999, edition sigma

Dieter Köster

Wettbewerb in Netzproduktmärkten

1999, Deutscher Universitäts-Verlag

Christian Wey

Marktorganisation durch Standardisierung: Ein

Beitrag zur Neuen Institutionenökonomik des Marktes 1999, edition sigma

Horst Albach, Meinolf Dierkes, Ariane Berthoin Antal, Kristina Vaillant $(\mathrm{Hg}$.

Organisationslernen - institutionelle und kulturelle

Dimensionen

WZB-Jahrbuch 1998

1998, edition sigma

Lars Bergman, Chris Doyle, Jordi Gual, Lars

Hultkrantz, Damien Neven, Lars-Hendrik Röller,

Leonard Waverman

Europe's Network Industries: Conflicting

Priorities - Telecommunications

Monitoring European Deregulation 1

1998, Centre for Economic Policy Research

Manfred Fleischer

The Inefficiency Trap

Strategy Failure in the

German Machine Tool Industry

1997, edition sigma

Christian Göseke

Information Gathering and Dissemination

The Contribution of JETRO to

Japanese Competitiveness

1997, Deutscher Universitäts-Verlag 
Fredrik Andersson Kai A. Konrad

Lars-Hendrik Röller Christian Wey

Talat Mahmood Klaus Schömann

Talat Mahmood Klaus Schömann

Jos Jansen

Jos Jansen

Günter Franke Harris Schlesinger Richard C. Stapleton

Tomaso Duso

Johan Lagerlöf

Paul Heidhues

Olivier Cadot Lars-Hendrik Röller Andreas Stephan

Justus Haucap

Christian Wey

Heidrun C. Hoppe Emre Ozdenoren

Rainer Nitsche

Daniel Krähmer

J. Peter Murmann

Kai A. Konrad

Robert Nuscheler

Fredrik Andersson Kai A. Konrad
Human Capital Investment and Globalization in Extortionary States

Merger Control in the New Economy

FS IV $02-02$

Die Determinanten der Mirgrationsentscheidung von IT-Hochschulabsolventen aus Pakistan Empirische Befunde zur Ausgestaltung der deutschen „Green Card“"

The Determinants of the Migration Decision of ITgraduates from Pakistan: Empirical Evidence for the Design of a German "Green Card"

The Effects of Disclosure Regulation on Innovative Firms: Common Values

The Effects of Disclosure Regulation on Innovative Firms: Private Values

Multiplicative Background Risk

FS IV $02-06$

On the Politics of the Regulatory Reform:

Econometric Evidence from the OECD Countries

On the Desirability of an Efficiency Defense in

Merger Control

Contribution to Productivity or Pork Barrel? The Two Faces of Infrastructure Investment

Unionization Structures and Firms' Incentives for Productivity Enhancing Investments

Intermediation in Innovation

FS IV $02-07$

FS IV $02-08$

FS IV $02-09$

FS IV $02-10$

FS IV $02-11$

FS IV $02-12$

FS IV $02-13$

Entry and Experimentation in

Oligopolistic Markets for Experience Goods

The Coevolution of Industries and National Institutions: Theory and Evidence

FS IV $02-14$

FS IV $02-15$

Terrorism and the State

FS IV $02-16$

Physician Reimbursement, Time-Consistency and the Quality of Care

Taxation and Education Investment in the Tertiary Sector 
Jan Boone

Helmut Bester

Kai A. Konrad

Kjell Erik Lommerud Bjørn Sandvik

Odd Rune Straume

Steffen Huck Vicki Knoblauch Wieland Müller

Ralph Siebert

Jürgen Bracht

Saul Lach

Eyal Winter

Steffen Huck

Kai A. Konrad

Daniel Krähmer

Thomas Knaus Robert Nuscheler

Kurt R. Brekke

Robert Nuscheler Odd Rune Straume

Kai A. Konrad

Sebastian Kessing

Sebastian Kessing

Michal Grajek

Robert M. Adams Lars-Hendrik Röller Robin C. Sickles

Tomaso Duso Damien J. Neven Lars-Hendrik Röller

Tomaso Duso Astrid Jung
'Be nice, unless it pays to fight': A New Theory of

Price Determination with Implications for

Competition Policy

Altruism and Envy in Contests:

An Evolutionarily Stable Symbiosis

Delay in Contests

Good Jobs, Bad Jobs and Redistribution

On the Profitability of Collusion in Location Games

Learning by Doing and Multiproduction Effects over the Life Cycle: Evidence from the Semiconductor Industry

Modeling Oligopolistic Price Adjustment in Micro Level Panel Data

Strategic Trade Policy and the Home Bias in Firm Ownership Structure

Delegation versus Authority

Incomplete Risk Adjustment and Adverse

Selection in the German Public Health Insurance System

Quality and Location Choices under Price Regulation

Inverse Campaigning

A Note on the Determinants of Labour Share Movements

Employment Protection and Product Market Competition

Identification of Network Externalities in Markets for Non-Durables

Market Power in Outputs and Inputs: An Empirical Application to Banking

The Political Economy of European Merger

Control: Evidence using Stock Market Data

Market Conduct and Endogenous Lobbying: Evidence from the U.S. Mobile Telecommunications Industry
FS IV $02-20$

FS IV $02-21$

FS IV $02-22$

FS IV $02-28$

FS IV $02-29$

FS IV $02-18$

FS IV $02-19$

FS IV $02-23$

FS IV $02-24$

FS IV $02-25$

FS IV $02-26$

FS IV $02-27$

FS IV $02-30$

FS IV $02-31$

FS IV $02-32$

FS IV $02-33$

FS IV $02-34$

FS IV $02-35$ 
Annette Boom

Kai A. Konrad Wolfram F. Richter

Stergios Skaperdas

Johan Lagerlöf

Roman Inderst

Christian Wey

Sebastian Kessing Robert Nuscheler

Lars Frisell

Paul Heidhues Nicolas Melissas

Pablo Beramendi
Investments in Electricity Generating Capacity under Different Market Structures and with Endogenously Fixed Demand

Zur Berücksichtigung von Kindern bei umlagefinanzierter Alterssicherung

Restraining the Genuine Homo Economicus: Why the Economy cannot be divorced from its Governance

Insisting on a Non-Negative Price: Oligopoly, Uncertainty, Welfare, and Multiple Equilibria

Buyer Power and Supplier Incentives

Monopoly Pricing with Negative Network Effects: the Case of Vaccines

The Breakdown of Authority

Equilibria in a Dynamic Global Game: The Role of Cohort Effects

Political Institutions and Income Inequality: the case of Decentralization
SP || $2003-$ 01

SP || $2003-$ 02

SP || $2003-$ 03

SP || 2003 04

SP || 2003 05

SP || 2003 06

SP || 2003 07

SP || 2003 08

SP II 2003 09 
Bestellschein

Absender / Return Address:

Wissenschaftszentrum Berlin für Sozialforschung Presse- und Informationsreferat Reichpietschufer 50

D-10785 Berlin-Tiergarten

Hiermit bestelle ich folgende(s) Discussion paper(s):

Bestell-Nr. / Order no.
Please send me the following Discussion paper(s):

Autor/in, Kurztitel /Author(s) / Title(s) in brief 